\title{
Evaluation of Skin and Respiratory Symptoms among Employees with Exposure to Metals, Metalworking Fluids, and Noise at an Orthopedic Implant Manufacturer
}

Catherine Beaucham, MPH, CIH Loren Tapp, MD, MS Charles Mueller, MS Aalok Y. Oza, MPH

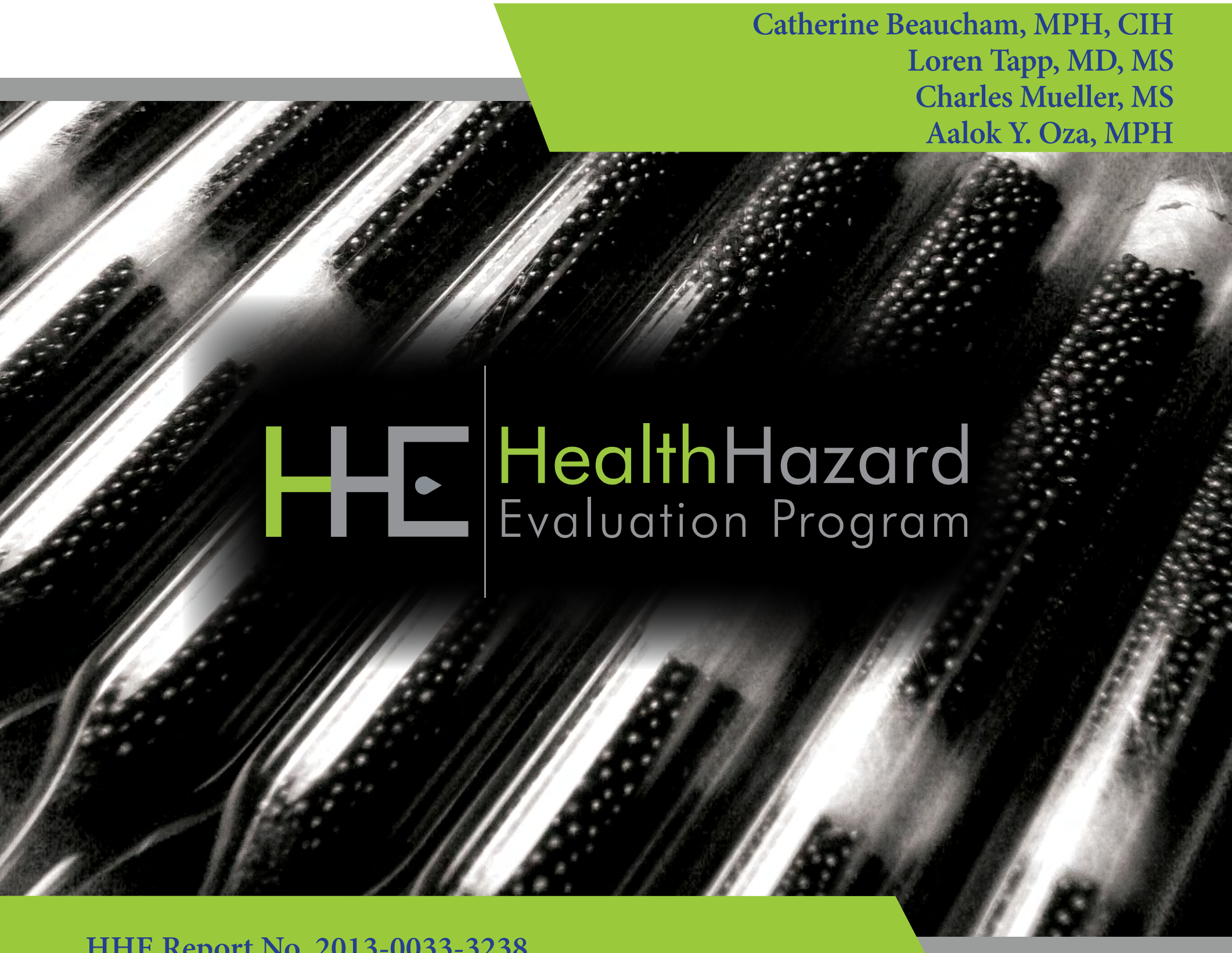

HHE Report No. 2013-0033-3238

July 2015 


\section{Contents}

Highlights i

Abbreviations ...................................... iii

Introduction ............................................ 1

Background ............................................1

Methods .............................................. 3

Results ................................................ 7

Conclusions ........................................ 20

Recommendations ............................ 20

Appendix A ....................................... 23

Appendix B .......................................... 28

References ........................................... 34

Acknowledgements ......................... 39

The employer is required to post a copy of this report for 30 days at or near the workplace(s) of affected employees. The employer must take steps to ensure that the posted report is not altered, defaced, or covered by other material.

The cover photo is a close-up image of sorbent tubes, which are used by the HHE Program to measure airborne exposures. This photo is an artistic representation that may not be related to this Health Hazard Evaluation. Photo by NIOSH. 


\section{Highlights of this Evaluation}

The Health Hazard Evaluation Program received a confidential request from employees who were concerned about exposures to mold, metalworking fluid mists, and metals at an orthopedic implant manufacturer. Our evaluation was in one building (building 2402) that manufactured cobalt chromium femoral implants, titanium femoral stem implants, and plastic patellar implants.

\section{What We Did}

- We looked at employee work practices.

- We tested the air and work surfaces for metals.

- We tested the air for metalworking fluid mist.

- We reviewed company records on air tests and written policies and procedures.

- We asked employees about their health and work-related symptoms using interviews and questionnaires.

- We collected urine from employees to check their cobalt and chromium levels.

- We measured noise levels.

\section{What We Found}

- One air cobalt level in the finishing area was above the most protective exposure limit.

- Cobalt and chromium levels in employee urine samples were low.

- Working as a femoral finisher was associated with having nasal and skin symptoms. These symptoms could be related to cobalt dust exposure.

- Femoral finishers doing box polishing had exposure to low levels of hexavalent chromium, a known carcinogen.

We assessed exposure to metals, metalworking fluids, and noise at an orthopedic implant manufacturer. We measured an overexposure to cobalt before local exhaust ventilation system improvements were made. We also measured overexposures to noise. One air sample for hexavalent chromium was more than half the NIOSH REL. Working as a femoral finisher was associated with having nasal and skin symptoms, suggesting symptoms could be related to cobalt dust exposure. We recommended improving engineering controls, starting a hearing conservation program, improving employee training, and doing medical evaluations for employees with persistent work-related symptoms.

- Some surfaces in the break room were contaminated with cobalt, chromium, and aluminum.

- Some noise exposures were above the limits set by the Occupational Safety and Health Administration and most noise exposures by the polishing and buffing stations and in the nitric passivation room were above the limits set by the National Institute for Occupational Safety and Health. 


\section{What the Employer Can Do}

- Implement better engineering controls (for protection from metals and noise exposures) and a hearing conservation program.

- Train employees to recognize work hazards and prevent exposures.

- Stop employees from using compressed air to clean work clothing.

- Measure finishing department employee exposures to hexavalent chromium to find out if new exposure controls or medical monitoring is needed.

- Encourage employees to report potential work-related health conditions to their supervisor. Employees with persistent symptoms should be evaluated by an occupational medicine physician.

- Stop using latex gloves because of the potential for allergic reactions to latex.

- Require nitrile glove use when skin contact with metalworking fluids or metal dust is possible.

\section{What Employees Can Do}

- Stop using compressed air to clean work clothing.

- Remove gloves and wash hands when leaving the production area.

- Report symptoms and health concerns to your supervisor.

- Inform your doctor about your exposure to chromium and cobalt metals.

- Wear nitrile gloves when skin contact with metalworking fluids or metal dust is possible.

- Use hearing protection when working at the polishing and buffing stations and in the nitric passivation room. 


\section{Abbreviations}

$\begin{array}{ll}\mu \mathrm{g} & \text { Micrograms } \\ \mu \mathrm{g} / 100 \mathrm{~cm}^{2} & \text { Micrograms per 100 squared centimeters } \\ \mu \mathrm{g} / \mathrm{L} & \text { Micrograms per liter } \\ \mu \mathrm{g} / \mathrm{m}^{3} & \text { Micrograms per cubic meter } \\ \mathrm{ACGIH} & \text { American Conference of Governmental Industrial Hygienists } \\ \mathrm{AL} & \text { Action level } \\ \mathrm{BEI}{ }^{\circledR} & \text { Biological exposure index } \\ \mathrm{CFR} & \text { Code of Federal Regulations } \\ \mathrm{dBA} & \text { Decibels, A-scale } \\ \mathrm{Hz} & \text { Hertz } \\ \mathrm{MWF} & \text { Metalworking fluid } \\ \mathrm{MDC} & \text { Minimum detectable concentration } \\ \text { MQC } & \text { Minimum quantifiable concentration } \\ \text { ND } & \text { Not detected } \\ \text { NIOSH } & \text { National Institute for Occupational Safety and Health } \\ \text { OEL } & \text { Occupational exposure limit } \\ \text { OSHA } & \text { Occupational Safety and Health Administration } \\ \text { PEL } & \text { Permissible exposure limit } \\ \text { REL } & \text { Recommended exposure limit } \\ \text { STEL } & \text { Short-term exposure limit } \\ \text { TLV® } & \text { Threshold limit value } \\ \text { TWA } & \text { Time-weighted average } \\ \text { WEEL } & \text { Workplace environmental exposure level }\end{array}$




\section{This page left intentionally blank}




\section{Introduction}

The Health Hazard Evaluation Program received a confidential request from employees at an orthopedic implant manufacturer. The request concerned exposures associated with machining of cobalt-chromium and titanium stem femoral implants, and mold from a water leak in the employee break area. Employees were concerned that these exposures were causing respiratory problems. We visited the facility in February and June 2013. We sent letters to the employer and employees with initial findings and recommendations in March and August 2013.

\section{Background}

The company began operations in the 1980s, manufacturing orthopedic joint-replacement products and surgical instruments for use in hip, knee, shoulder, and other orthopedic surgical procedures. At the time of our evaluation, the company had nine buildings and operated 5 or 6 days a week, with two 8-hour shifts per day. Approximately 400 employees worked for the company. Twenty-six employees (all non-union) worked in the building of concern (building 2402), where plastic patellas (knee caps), cobalt-chromium femoral implants (used for knee joint replacement), and titanium stem femoral implants (used for hip joint replacement) were manufactured. All employees were required to wear safety glasses and steel-toe boots; company-issued coveralls, earplugs, protective gloves, and respirator use were optional and varied by department.

In fall 2012, an anonymous complaint to the Occupational Safety and Health Administration (OSHA) resulted in a visit by a state consultation program working in cooperation with the OSHA Safety and Health Achievement Recognition Program. The complaint concerned employee exposures to mold in the employee break room and to oil mist in the production area of the building we later evaluated. In October 2012, a consultant collected personal and area air samples for oil mist and dust. The concentrations of oil mist and total dust were below the OSHA permissible exposure limits (PELs). The consultant did not analyze the dust samples for metals. Mold was discovered in the break room. The break room was closed, and remediation was performed prior to our first visit.

\section{Process Description}

\section{Plastic Implants}

The facility produced plastic prosthetic patellas by slicing polyethylene rods with an electric chain-driven saw. The employees used a handheld burr grinder to remove irregularities in the polyethylene slices. A local exhaust ventilation hose attached to a vacuum pump removed dust. The employees processed the slices in a mill and then a lathe to shape the plastic slices into prosthetic patellas. The plastic implant mill used one type of water-soluble metalworking fluid (MWF). Employees wore latex gloves. Some employees wore an N95 filtering facepiece respirator and earplugs, both of which were optional. 


\section{Metal Implants}

\section{Cobalt-Chromium Femoral Implants}

The employees in the building of concern machined and finished cobalt-chromium femoral implants used for prosthetic knee joints. Four enclosed grinding machines with mist collectors processed up to six implants at a time, depending on the model. Three employees worked in femoral machining and three in plastic patella machining. The facility used two types of MWFs for the femoral implant grinders. The Haas ${ }^{\circledR}$ grinders used Blasomill ${ }^{\circledR}$ $10 \mathrm{MWF}$ and the Walter ${ }^{\circledR}$ grinder used Sintogrind ${ }^{\circledR}$ TTS. A third type of MWF, Blasocut 2000, was used in the plastic patellar implant lathe. No biocides were added to the MWFs. After a machining cycle was complete, machinists manually removed the implants, wiped off excess MWF with a paper towel, and washed the implants in an open basin containing an alkaline cleaning solution. The machinists did not wear gloves when handling the implants.

After cleaning, machinists transferred the implants to the finishing department where eleven employees worked femoral finishing. Femoral finishing tasks included coarse polishing, box polishing, buffing, drag finishing, "mask and blast," and "trim and blast." Femoral finishing employees first removed irregularities using a large belt sander at the coarse polishing station, then transferred the implants to the box polishing station (Figure 1). At this station, finishers used a small belt sander with a thin abrasive strip to polish the sharper angles and bends on the implants. Some employees wore an N95 filtering facepiece respirator and earplugs.

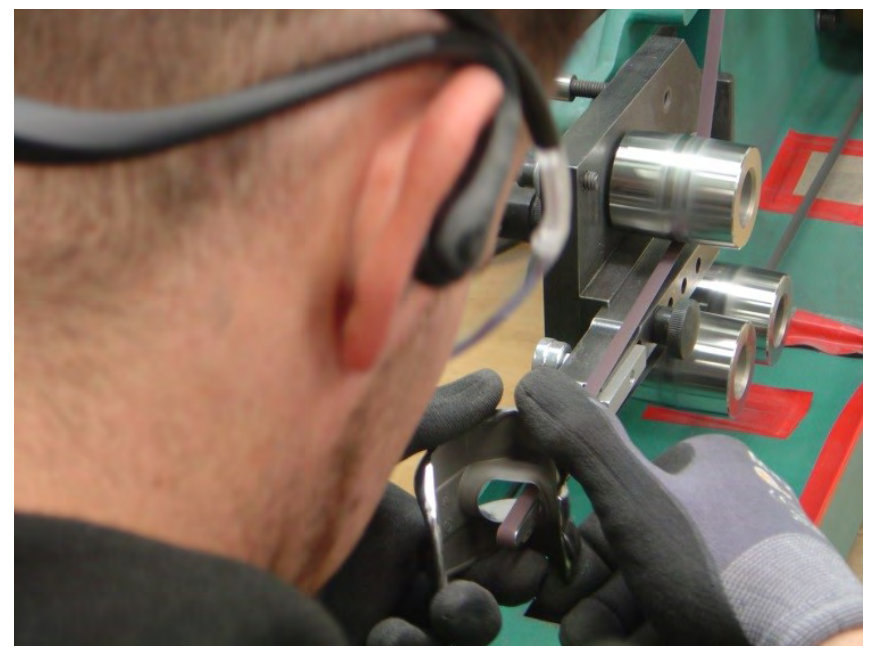

Figure 1. Box polish station. Photo by NIOSH.

The coarse polishing station and box polishing station generated dusts that could contain cobalt and chromium. Femoral finishing employees may also be exposed to hexavalent chromium in this setting when polishing cobalt-chromium parts because "hot work" such as grinding on chromium sometimes generates hexavalent chromium [OSHA 2015]. When polishing and buffing, employees wore cut-resistant, palm-coated gloves; safety glasses; and steel toe boots. Some employees wore an N95 filtering facepiece respirator, company-issued coveralls, and earplugs. 
Following box polishing, the implants were polished in a large tumbler filled with a ceramic abrasive, a process called drag finishing. Then finishing employees used a cloth wheel and buffing compound at one of the finishing stations to remove scratches and abrasions from the surface of the femoral implant. This buffing compound contained aluminum oxide. Some employees wore an N95 filtering facepiece respirator, company-issued coveralls, and earplugs.

Finishing employees then cleaned the parts, dipped them with a gloved hand into a $350^{\circ} \mathrm{F}$ molten plastic sealant, and sandblasted the exposed surface of the implant in an enclosed cabinet. This task was called mask and blast. The finishers carefully inspected each part for imperfections and removed the part with a hand-held tool. This task was called trim and blast. The implants were transferred to the passivation room where they were cleaned with methyl ethyl ketone by two employees wearing gloves and then dipped into a nitric acid passivation tank to prevent corrosion. These employees wore latex gloves, steel toe boots, safety glasses, and a disposable apron. Some employees wore an N95 filtering facepiece respirator and earplugs.

\section{Titanium Stem Implants}

The titanium femoral stems used in prosthetic hip joints were also finished in this building. Two employees (titanium stem finishers) polished the stems with a belt sander and then transferred them to a tumbler/polisher filled with ceramic, plastic, or corncob abrasive polishing media. Employees sandblasted the stem heads inside of a glove box-type enclosure to create a coarse surface to permit bone attachment. Employees then transferred finished parts to the passivation room for a dip into the nitric acid passivation process described above.

\section{Methods}

We had the following four objectives for this evaluation:

1. Assess work-related health concerns of employees

2. Evaluate employees' exposures to mold, dusts, MWFs, and metals

3. Qualitatively evaluate the effectiveness of the local exhaust ventilation systems

4. Assess noise exposures associated with different jobs

In February 2013, we met with employer and employee representatives to discuss the health hazard evaluation request and evaluate the building of concern. During this initial visit, we walked through the building to become familiar with the layout and to observe work processes, practices, and conditions. We held confidential medical interviews, reviewed reports and records, collected air and surface samples to analyze for dust, metals, and MWF; measured sound levels; and examined the break room area for mold growth and moisture. We performed a follow-up visit in June 2013 to further evaluate metal and noise exposures. We also administered a health questionnaire to employees, collected employee urine samples to analyze for metals, and examined changes implemented between the two visits. Information on health effects and occupational exposure limits (OELs) for the contaminants we measured can be found in Appendix B. 


\section{Employee Interviews and Records Review}

In February 2013, we confidentially interviewed all 26 employees working in the building of concern about their medical and work history, and we reviewed medical records of employees with health problems they thought might be work-related. We reviewed the OSHA Form 300 Logs of Work-Related Injuries and Illnesses and workers' compensation claims from 2010 through 2012. In addition, we reviewed the facility's safety and health program, hazard communication program, and respiratory protection program.

\section{Contaminant Sampling, Ventilation Assessment, and Observations}

In February 2013, we took personal and area air samples for total particulate, metals (chromium, cobalt, and titanium), and MWF over two work shifts to identify work locations and processes where employees had the highest potential for airborne exposure. We also collected personal and area air samples for hexavalent chromium to learn whether the manufacturing process was generating this hazardous compound from the chromium metal in the femoral implants. In this report, we use the term "chromium" for chromium metal and all compounds containing chromium (in the trivalent and hexavalent states) and use the term "hexavalent chromium" for chromium compounds that exist only in the hexavalent state which is considered a more toxic form of chromium (see Appendix B for explanation). We collected surface wipe samples throughout the facility to evaluate housekeeping effectiveness. Table 1 lists the number of samples we collected and the sampling and analytical methods we used. We analyzed the chromium, cobalt, and titanium in air samples by the National Institute for Occupational Safety and Health (NIOSH) Method 7303 [NIOSH 2014a], with modification. The modification included wiping the interior walls of the filter cassette with a wet smear tab to collect particles on the inside walls. The smear tab was then analyzed along with the filter sample as recommended by NIOSH [2014b].

We observed work practices and examined the local exhaust ventilation system at the box polishing station and nitric passivation tank using smoke tubes to help visualize airflow. We also examined the newly renovated break room area for visual signs of mold growth or water damage. We opened all of the newly installed cabinets to look for pooled water or stains on the wood. 
Table 1. Air and surface sampling and analytical methods, February 2013

\begin{tabular}{lccc}
\hline Analyte & $\begin{array}{c}\text { Total number of } \\
\text { personal samples } \\
\text { collected }\end{array}$ & $\begin{array}{c}\text { Total number of } \\
\text { area samples } \\
\text { collected }\end{array}$ & $\begin{array}{c}\text { NIOSH } \\
\text { method } \\
\text { number }\end{array}$ \\
\hline Hexavalent chromium in air & 4 & 7 & 7605 \\
MWFs in air & 3 & 7 & 5524 \\
Total particulate in air & 9 & 10 & 0500 \\
Chromium, cobalt, and titanium in airt & 10 & Not applicable & 7303 \\
Chromium, cobalt, and titanium on surfaces & Not applicable & 15 & 9102 \\
\hline${ }^{*}[\mathrm{NIOSH} 2014]$ & & &
\end{tabular}

†Total particulate, chromium, titanium, and cobalt in air were collected on the same filter.

In June 2013, we evaluated employee exposures to aluminum, chromium, cobalt, and titanium in air and on surfaces. In addition, we collected and analyzed bulk samples of the used and unused MWF for cobalt and chromium (Table 2). We also noted changes in work practices and local exhaust ventilation systems.

Table 2. Air, surface, and bulk sampling and analytical methods, June 2013

\begin{tabular}{lccc}
\hline Analytes & $\begin{array}{c}\text { Total number of } \\
\text { personal samples } \\
\text { collected }\end{array}$ & $\begin{array}{c}\text { Total number of } \\
\text { area samples } \\
\text { collected }\end{array}$ & $\begin{array}{c}\text { NIOSH } \\
\text { method } \\
\text { number* }\end{array}$ \\
\hline $\begin{array}{l}\text { Aluminum, chromium, cobalt, and } \\
\text { titanium in air }\end{array}$ & 16 & Not applicable & $7303 \dagger$ \\
$\begin{array}{l}\text { Cobalt and chromium in bulk MWF } \\
\begin{array}{l}\text { Aluminum, chromium, cobalt, and } \\
\text { titanium on surfaces }\end{array}\end{array}$ & Not applicable & 4 & $7303 \ddagger$ \\
${ }^{*}[$ NIOSH 2014] & Not applicable & 11 & 9102 \\
& & & \\
$\ddagger$ †odified to address sampler wall losses & & & \\
$\ddagger$ Modified for liquid matrix & & &
\end{tabular}

\section{Questionnaire}

In June 2013, we asked all 26 employees in the building to complete a written questionnaire. The questionnaire asked about demographics, work and medical history, personal protective equipment use, and tobacco use. We asked about possible non-work exposures to cobalt and chromium that could affect the urinalysis results. These exposures included painting, staining, or glazing with cobalt- or chromium-containing pigments; taking vitamins that contain Vitamin B12, or cyanocobalamin, a form of cobalt; or having joint replacement surgery with a metal replacement joint [ACGIH 2001]. We also asked about skin, nasal, and respiratory symptoms and whether these symptoms changed on days off work.

We compared symptoms of employees exposed to chromium and cobalt dust with symptoms of employees having minimal or no chromium and cobalt dust exposure. We also compared symptoms of employees exposed to MWF with symptoms of employees with minimal or 
no MWF exposure. We based the workplace exposure groups on employee job titles and observations. We evaluated relationships between workplace exposure groups and symptoms by using Fisher's exact test. All statistical analyses were done with SAS statistical software version 9.3. All tests were two-tailed, and statistical significance was set at $P<0.05$. We looked at symptoms that improved on days away from work as an indication of potential work-relatedness.

\section{Biological Exposure Monitoring}

We asked employees to provide an end-of-shift, end-of-workweek urine sample to analyze for urinary cobalt and chromium levels. We obtained their consent to participate. The urine analyses provided a measure of recent exposure to cobalt and chromium metals. We also measured creatinine in the urine to see how well the participants' kidneys were functioning; if the creatinine level is too high or too low, the urine is too concentrated or dilute so that the cobalt and chromium results are not accurate and cannot be reported. Urine samples were collected in acid-washed containers, kept cold, and shipped overnight to the laboratory. The samples were analyzed for cobalt and chromium by inductively coupled plasma mass spectrometry, which is capable of detecting metals at concentrations as low as one part per trillion.

We compared the cobalt and chromium urine concentration results to OELs where available (see Appendix B).

\section{Comparing Questionnaire, Contaminant Sampling, and Biomonitoring Data}

We compared urine and air cobalt levels among employee groups based on job titles and exposure information reported on the questionnaire by using Wilcoxon tests. For the 12 employees who had both types of measurements, we also compared their urine cobalt levels with their air cobalt levels. Four of these 12 participants had two air sample measurements each. We used the average of the two air measurements to obtain a single measurement to use in our calculations. We evaluated the correlation between air and urine cobalt levels by using the Spearman correlation coefficient.

\section{Noise Monitoring}

In February 2013, we measured area sound levels, using a Larson Davis Model 824 integrating sound level meter. We documented the highest sound levels in approximately a 1-minute period at each location to evaluate potential areas of concern and to identify areas for subsequent evaluation with noise dosimetry.

During our visit in June 2013, we took 17 full-shift time-weighted average (TWA) personal noise exposure measurements on employees over two shifts. We used Larson Davis Spark ${ }^{\mathrm{TM}}$ model 706RC integrating noise dosimeters. The noise dosimeters were attached to the wearer's belt, and a small microphone was fastened to the wearer's shirt at a point midway between the ear and outside of the shoulder. Windscreens provided by the dosimeter 
manufacturer were placed over the microphones to reduce or eliminate artifact noise, which can occur if objects bump against unprotected microphones. The dosimeters simultaneously collected data with three different settings to allow comparison of noise measurements at three different noise exposure limits: the OSHA PEL, OSHA action level (AL), and NIOSH recommended exposure limit (REL). The dosimeters averaged noise levels every second. Noise levels below the threshold level are not integrated into the dose calculation of noise levels. We downloaded the noise measurement information from the dosimeters with Larson Davis Blaze ${ }^{\circledR}$ software. We calibrated the dosimeters before and after the measurement periods according to the manufacturer's instructions.

\section{Results}

\section{Employee Interviews and Record Review}

\section{Interviews}

We interviewed all 26 employees working in the building during first and second shifts. Most interviewed employees $(n=19)$ did not report symptoms that they thought were work-related or concerns about their work environment. However, seven (27\%) reported having nasal and/ or sinus symptoms (nasal congestion, runny nose, sinus headache, post-nasal drip); five of the seven reported that symptoms were aggravated by work or improved away from work. Some employees reported blowing "black" from their noses. Three of the seven employees also reported respiratory symptoms (cough, shortness of breath, chest tightness, or wheezing) that improved away from work, and one reported skin symptoms that improved away from work.

\section{Medical Records Review}

We reviewed medical records of seven employees who had seen a medical provider for sinus, respiratory, or skin symptoms. Two of the employees' records did not provide evidence of a work-related health condition. The other five employees were medically evaluated for sinus symptoms; three were diagnosed with sinusitis, two on the basis of abnormal computerized tomography findings. Three of the five with sinus symptoms were also evaluated for respiratory symptoms (shortness of breath, wheezing, and chest tightness). Medical diagnoses for these three employees included pneumonia, "asthma-like symptoms," reactive airway disease, and chemical inhalation (one of the employees had more than one diagnosis). Two of these three employees were referred to a lung specialist and told to avoid workplace chemicals.

\section{OSHA Form 300 Logs of Work-related Injury and Illness Record Review}

There were 14 entries in the OSHA Logs of 2010-2012 for the entire facility. The majority of entries $(n=10)$ were for musculoskeletal injuries or disorders. There was one entry in 2012 for smoke inhalation injury.

\section{Workers' Compensation Claims Record Review}

The company had 13 claims during years 2010, 2011, and 2012. The pertinent claims from employees of the building we evaluated included two for respiratory disorders thought to be 
due to MWF or dust exposure, one for a smoke inhalation injury from responding to a fire in a machine, and one for a sinus disorder thought to be due to dust exposures at work. Job titles of these employees included femoral finisher, machinist, and maintenance technician.

\section{Program Review}

A review of the safety program suggested that management and employee participation was encouraged. The internal safety consultant team and the lead safety team were responsible for performing safety inspections, accident investigations, and job hazard analyses. The safety plan also described the safety training, including new-employee orientation, specific safety and health programs, and job-specific safety training, as coordinated by the team leader.

The written hazard communication program had the elements required by 29 Code of Federal Regulations (CFR) 1910.1200, except that it did not list cobalt, chromium, or titanium as hazardous chemicals that were present in the workplace. The hazardous chemicals list and safety data sheets were maintained by the occupational safety and health coordinator. The program included provisions for labels to be consistent with the globally harmonized system of classification and labelling of chemicals and secondary container labelling. Reportedly, training was performed prior to assignment in a specific department and whenever chemical hazards or job assignments changed but this training did not include the specific hazards associated with cobalt, chromium, or titanium.

The written respiratory protection program had the required elements from 29 CFR 1910.134, including medical evaluation; fit testing; proper use, maintenance, and care of respirators; training; voluntary use of N95 filtering facepiece respirators; types of respirators permitted at the facility; and locations where specific respirators were authorized. We observed that all particulate filter cartridges were marked with the date they were issued and when the employer required that they be replaced with new cartridges.

\section{Sampling, Ventilation Assessment, and Observations}

\section{Air Sampling}

Results of personal air samples for total particulate, chromium, cobalt, and titanium from February 2013 are in Table 3. One personal air sample for cobalt taken on femoral finisher number 2 doing box polishing [26 micrograms per cubic meter of air $\left.\left(\mu \mathrm{g} / \mathrm{m}^{3}\right)\right]$ exceeded the American Conference of Governmental Industrial Hygienists (ACGIH®) threshold limit value (TLV®) of $20 \mu \mathrm{g} / \mathrm{m}^{3}$. The air sample results for femoral finisher number 2 for other contaminants $\left(2,100 \mu \mathrm{g} / \mathrm{m}^{3}\right.$ for total particulate and $10 \mu \mathrm{g} / \mathrm{m}^{3}$ for chromium) were also higher than those for other employees, although they did not exceed applicable exposure limits. There are no applicable OELs for total particulates in this situation; the results, however, are useful for assessing overall particulate exposure. On the first day of sampling, two femoral finishers doing box polishing rotated in and out of the box polishing station based on the need for that task to be performed; therefore, at any given time throughout the day, there was either one, two, or three femoral finishers doing box polishing at the same time. Femoral finisher number 2, whose cobalt concentration exceeded the ACGIH TLV, was consistently at the box polishing station throughout the entire work shift. Due to the configuration of the connecting 
ducts, when more than one box polishing station was in use, the local exhaust ventilation was not increased but was split among the box polishing stations in use. On the following day, only one box polishing station was used for most of the day by one employee.

Table 3. Personal air sample result concentrations for total particulate, chromium, cobalt, and titanium, February 2013

\begin{tabular}{|c|c|c|c|c|c|c|}
\hline Job title & Job task & $\begin{array}{c}\text { Sample } \\
\text { duration } \\
\text { (minutes) }\end{array}$ & $\begin{array}{c}\text { Total } \\
\text { particulate } \\
\left(\mu \mathrm{g} / \mathrm{m}^{3}\right)\end{array}$ & $\begin{array}{c}\text { Chromium } \\
\left(\mu \mathrm{g} / \mathrm{m}^{3}\right)\end{array}$ & $\begin{array}{l}\text { Cobalt } \\
\left(\mu \mathrm{g} / \mathrm{m}^{3}\right)\end{array}$ & $\begin{array}{l}\text { Titanium } \\
\left(\mu \mathrm{g} / \mathrm{m}^{3}\right)\end{array}$ \\
\hline \multicolumn{7}{|l|}{ Day 1} \\
\hline Metal machinist \#1 & $\begin{array}{l}\text { Machine } \\
\text { femorals }\end{array}$ & 452 & 69 & 0.24 & 0.35 & 0.080 \\
\hline Femoral finisher \#1 & $\begin{array}{l}\text { Femoral } \\
\text { buffer }\end{array}$ & 439 & 84 & ND & 0.55 & 0.093 \\
\hline Femoral finisher \#2 & Box polisher & $228^{*}$ & 2100 & 10 & 26 & 0.53 \\
\hline Plastic machinist \#1 & $\begin{array}{l}\text { Machine } \\
\text { patellas }\end{array}$ & 423 & 74 & 0.99 & 2.6 & 0.42 \\
\hline $\begin{array}{l}\text { Maintenance } \\
\text { tech \#1 }\end{array}$ & Maintenance & 376 & 1900 & 1.3 & 3.1 & 9.0 \\
\hline $\begin{array}{l}\text { Maintenance } \\
\text { tech \#2 }\end{array}$ & Maintenance & 383 & 810 & 0.5 & 1.4 & 3.2 \\
\hline \multicolumn{7}{|l|}{ Day 2} \\
\hline $\begin{array}{l}\text { Titanium stem } \\
\text { finisher \#1 }\end{array}$ & $\begin{array}{c}\text { Titanium } \\
\text { sandblaster }\end{array}$ & 447 & 220 & 0.26 & 0.56 & 0.50 \\
\hline Femoral finisher \#1 & Box polisher & 439 & 140 & 2.2 & 4.9 & 0.25 \\
\hline $\begin{array}{l}\text { Maintenance } \\
\text { tech \#1 }\end{array}$ & Maintenance & 429 & 62 & ND & 0.25 & 0.13 \\
\hline Plastic machinist \#1 & $\begin{array}{l}\text { Machine } \\
\text { patellas }\end{array}$ & 446 & 7 & 0.65 & $(0.17) \dagger$ & 0.042 \\
\hline NIOSH REL & & - & $\begin{array}{c}\text { Not } \\
\text { applicable }\end{array}$ & 500 & 50 & $\begin{array}{c}\text { Not } \\
\text { applicable }\end{array}$ \\
\hline OSHA PEL & & - & $\begin{array}{c}\text { Not } \\
\text { applicable }\end{array}$ & 1,000 & 100 & $\begin{array}{c}\text { Not } \\
\text { applicable }\end{array}$ \\
\hline ACGIH TLV & & - & $\begin{array}{c}\text { Not } \\
\text { applicable }\end{array}$ & 500 & 20 & $\begin{array}{c}\text { Not } \\
\text { applicable }\end{array}$ \\
\hline \multicolumn{2}{|c|}{ Minimum detectable concentration } & - & 0.02 & 0.04 & 0.06 & 0.007 \\
\hline \multicolumn{2}{|c|}{ Minimum quantifiable concentration } & - & 0.091 & 0.15 & 0.19 & 0.030 \\
\hline
\end{tabular}

The minimum detectable concentration (MDC) and the minimum quantifiable concentration (MQC) were determined on the basis of an average sampling duration of 406 minutes and sample volume of 812 liters.

ND $=$ Not detected

*This employee left work early on this day; 228 minutes was the employee's full-shift exposure.

†Values in parentheses are between the minimum detectable concentration and the minimum quantifiable concentration, meaning there is more uncertainty associated with these results. 
The maintenance technicians were exposed to dust when cleaning out the dry dust collector and were wearing full facepiece respirators with N95 particulate filters. The total particulate exposures for the maintenance technicians were $1,900 \mu \mathrm{g} / \mathrm{m}^{3}$ for one technician and $810 \mu \mathrm{g} / \mathrm{m}^{3}$ for the other; the chromium, cobalt, and titanium concentrations in those dust samples did not exceed applicable exposure limits. The maintenance technicians performed several tasks during the initial visit. The task that generated the highest concentration of dust was cleaning out the baghouse dust collector from the cobalt chromium grinding and polishing stations. This task involved two maintenance technicians who donned full facepiece respirators with N95 cartridges, hoodless Tyvek ${ }^{\circledR}$ suits, and latex gloves. These employees had been medically cleared, trained, and fit tested to wear respirators and were included in the facility's respiratory protection program. On the day of the evaluation we observed that the respirators were cleaned after use and stored in a sealed bag at the technicians' workstations. They removed each filter cylinder from the baghouse and poured the dust into a 55-gallon receptacle, then replaced the filter cylinders (Figure 2). They dry-swept the spilled dust, placed it into the drum, and then sealed the drum. They also cleaned the wet-dust-collection system using a hose and shovel while wearing the same personal protective equipment.

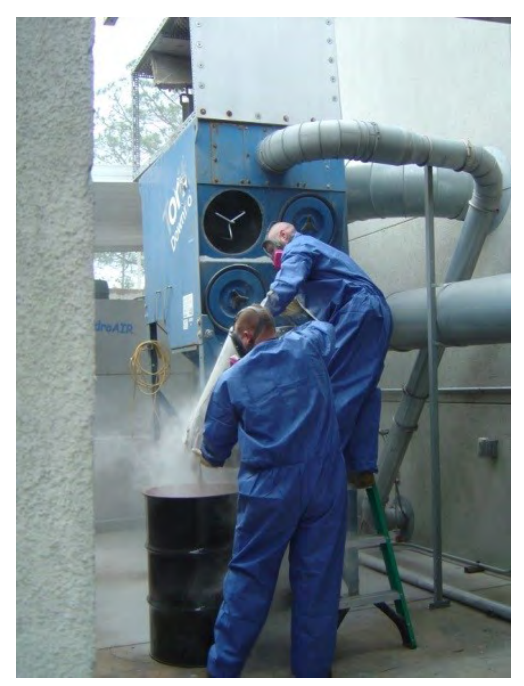

Figure 2. Maintenance technicians cleaning out the baghouse dust collector. Photo by NIOSH.

Personal and area air sampling results for hexavalent chromium are in Appendix A, Table A1 (personal samples) and Table A2 (area samples). One of the four personal air samples $\left(0.14 \mu \mathrm{g} / \mathrm{m}^{3}\right)$ and one of the seven area air samples $\left(0.081 \mu \mathrm{g} / \mathrm{m}^{3}\right)$ had quantifiable concentrations of hexavalent chromium.

The personal air sampling results for MWF measured as total particulate fraction are in Appendix A, Table A3. MWFs were detected in only one of the three personal air samples at $34 \mu \mathrm{g} / \mathrm{m}^{3}$, less than $10 \%$ of the NIOSH REL $\left(500 \mu \mathrm{g} / \mathrm{m}^{3}\right)$. Area air sampling results for MWF are in Appendix A, Table A4. Low concentrations of MWF were found on three of seven area air samples. These MWF sampling results were consistent with those previously reported by the consultant. 
In June 2013, all personal air sample concentrations of aluminum, chromium, cobalt, and titanium were well below their respective OELs (see Table 4). Detailed results for personal air samples are in Appendix A, Table A5. The highest cobalt concentrations (7.6 and $5.0 \mu \mathrm{g}$ cobalt $/ \mathrm{m}^{3}$ ) were measured on the femoral finishers working the first and second polishing and buffing stations (Table A5). In addition, these femoral finishers had the highest exposure to aluminum (4.5 and $3.6 \mu \mathrm{g}$ aluminum $/ \mathrm{m}^{3}$ ), which is not surprising because they used an aluminum buffing compound. The chromium concentration was also highest on the two femoral finishing employees who worked at these polishing stations $(2.7$ and $2.2 \mu \mathrm{g}$ chromium $/ \mathrm{m}^{3}$ ). The titanium concentrations collected on titanium stem polishers were low, ranging from "not detected" to $1.9 \mu \mathrm{g} / \mathrm{m}^{3}$.

Table 4. Summary of personal air sample concentration results, June 2013

\begin{tabular}{lcccc}
\hline Substance* $^{*}$ & $\begin{array}{c}\text { Sample } \\
\text { results }\end{array}$ & $\begin{array}{c}\text { OSHA PEL } \\
\left(\mu \mathrm{g} / \mathrm{m}^{3}\right)\end{array}$ & $\begin{array}{c}\text { NIOSH REL } \\
\left(\mu \mathrm{g} / \mathrm{m}^{3}\right)\end{array}$ & $\begin{array}{c}\text { ACGIH TLV } \\
\left(\mu \mathrm{g} / \mathrm{m}^{3}\right)\end{array}$ \\
\hline Aluminum & $\leq 4.5$ & 15,000 & 10,000 & $1,000 \dagger$ \\
Chromium & $\leq 2.7$ & 1,000 & 500 & 500 \\
Cobalt & $\leq 7.6$ & 100 & 50 & 20 \\
Titanium & $\leq 1.9$ & Not applicable & Not applicable & Not applicable \\
\hline
\end{tabular}

*16 samples were collected for each substance.

†This limit is for the respirable fraction of the dust, but we collected total dust samples, which includes the respirable fraction and larger, inhalable dust particles.

\section{Surface Sampling}

We detected chromium, cobalt, and titanium in most of the surface samples we collected on February 2013, including those from nonproduction areas (Appendix A, Table A6). As expected, samples collected in the production area had the highest levels of metals. The concentrations were lower in non-production areas. The floor in front of the men's restroom (9.4 micrograms per 100 squared centimeters $\left[\mu \mathrm{g} / 100 \mathrm{~cm}^{2}\right]$ chromium, $22 \mu \mathrm{g} / 100 \mathrm{~cm}^{2}$ cobalt), the break room floor $\left(3.1 \mu \mathrm{g} / 100 \mathrm{~cm}^{2}\right.$ chromium, $7.0 \mu \mathrm{g} / 100 \mathrm{~cm}^{2}$ cobalt $)$, the break room door handle $\left(2.9 \mu \mathrm{g} / 100 \mathrm{~cm}^{2}\right.$ chromium, $5.1 \mu \mathrm{g} / 100 \mathrm{~cm}^{2}$ cobalt $)$, and the refrigerator handle in the break room $\left(2.3 \mu \mathrm{g} / 100 \mathrm{~cm}^{2}\right.$ chromium, and $1.0 \mu \mathrm{g} / 100 \mathrm{~cm}^{2}$ cobalt $)$ had detectable levels of chromium $\left(1.0 \mu \mathrm{g} / 100 \mathrm{~cm}^{2}\right)$. We measured $3.1 \mu \mathrm{g} / 100 \mathrm{~cm}^{2}$ titanium on the break room door handle, however all other titanium results were between the limit of detection $\left(0.007 \mu \mathrm{g} / 100 \mathrm{~cm}^{2}\right)$ and $0.35 \mu \mathrm{g} / 100 \mathrm{~cm}^{2}$.

We performed additional wipe sampling in June 2013. Complete wipe sample testing results are in Appendix A, Table A7. We found chromium, cobalt, and titanium in nonproduction areas, including areas where employees ate and drank. These metals were also found inside employees' gloves. We found the highest aluminum level $\left(12 \mu \mathrm{g} / 100 \mathrm{~cm}^{2}\right)$ on the door handle to the break area. The highest chromium $\left(5.0 \mu \mathrm{g} / 100 \mathrm{~cm}^{2}\right.$ and $\left.4.8 \mu \mathrm{g} / 100 \mathrm{~cm}^{2}\right)$ and cobalt $\left(11 \mu \mathrm{g} / 100 \mathrm{~cm}^{2}\right.$ and $\left.11 \mu \mathrm{g} / 100 \mathrm{~cm}^{2}\right)$ levels were found on the break room counter by the coffee maker and the top stair to the break area, respectively. 


\section{Bulk MWF Sampling}

The three bulk samples of used MWF showed higher concentrations of chromium and cobalt than shown in the three unused MWFs.

\section{Ventilation}

The cobalt chromium femoral grinding and polishing operations had hard metal ventilation ducts terminating at a baghouse dust collector located outside, on the other side of the exterior wall from each process. Each polishing station was attached to the metal duct with plastic flexiduct (Figure 3). The box polishing station, located at the far end of the cobalt chromium polish area, was attached to the exhaust ventilation system with flexible duct that had to be manually opened by lifting a damper when the box polishing stations were used. The titanium stem grinding operation was attached to a wet dust collector, located next to the dry dusthandling system outdoors. The nitric passivation room had a recirculating air handler that passed air through a charcoal filter before releasing it back into the room (Figure 4).

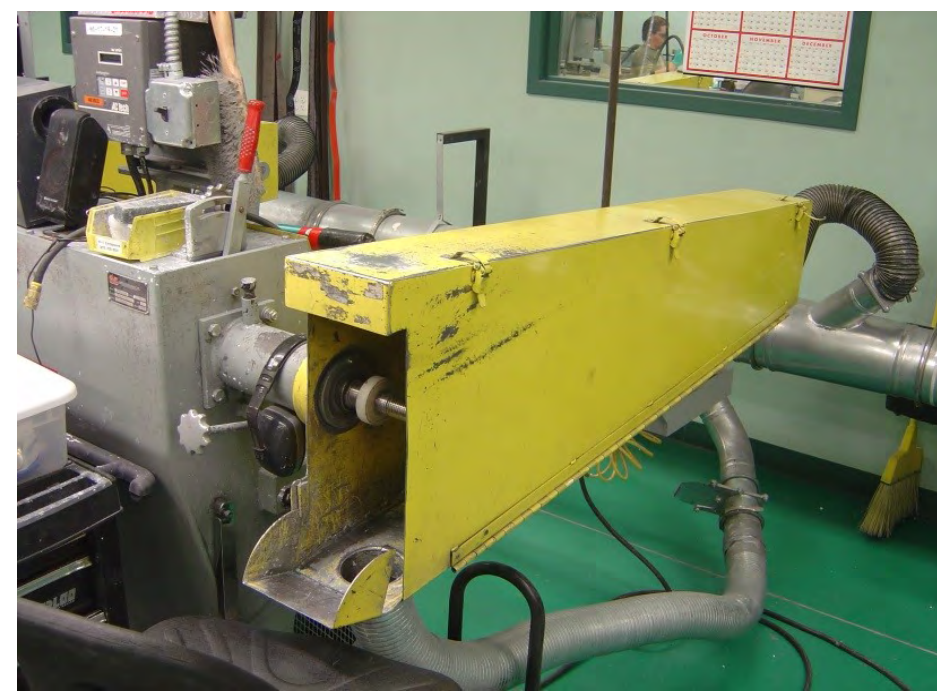

Figure 3. Local exhaust ventilation at one of the buffing/polishing stations. Photo by NIOSH.

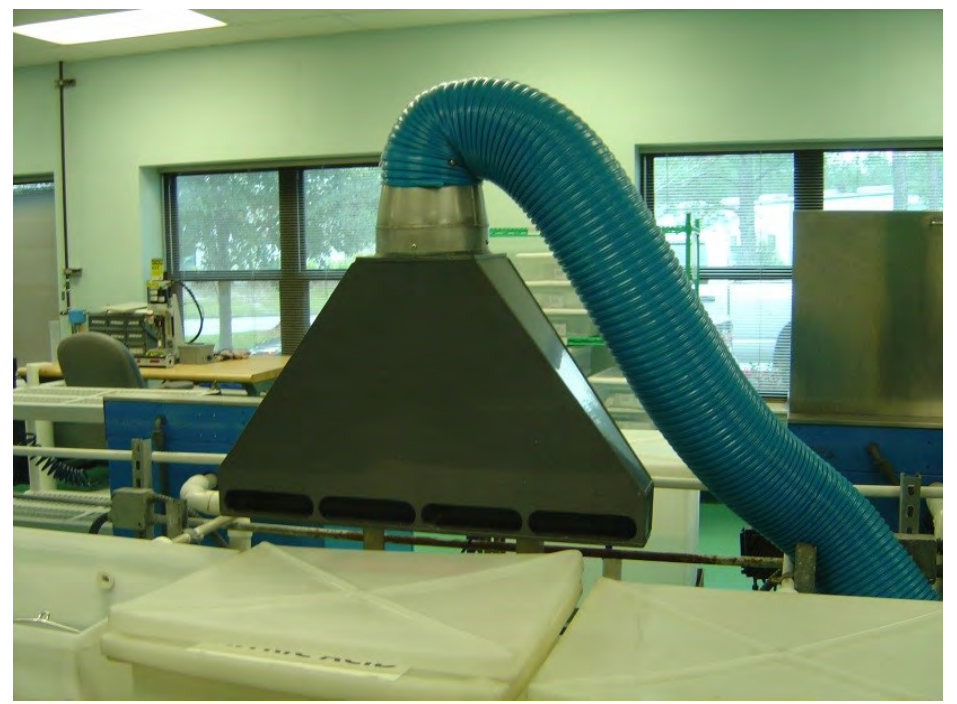

Figure 4. Local exhaust ventilation at the nitric acid passivation tank. Photo by NIOSH. 
Employees working at the box polishing station could be unnecessarily exposed to dust because the setup of the exhaust ventilation was not optimal. In February 2013, we found that the exhaust ventilation at the box polishing station was unable to capture smoke at the face of the femoral finisher doing box polishing. The ducts connected to this station had a $90^{\circ}$ turn and multiple twists in the flexible duct (Figure 5), features that reduce the capture velocity and thus the effectiveness of the local exhaust ventilation system.

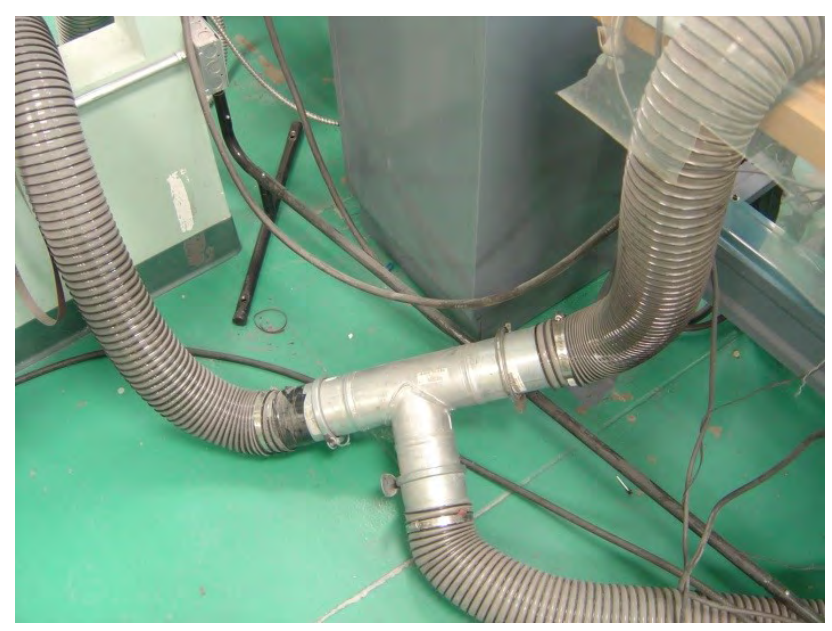

Figure 5. Local exhaust ventilation at the box polishing station. Photo by NIOSH.

The "metals only" burr grinders (adjacent to the patellar lathes) captured smoke poorly, indicating insufficient airflow. During our evaluation the maintenance technicians replaced the dust collector's filter bag in an attempt to improve performance. Afterward, the dust collector's ability to capture smoke improved. In the passivation room, the slot hood for the nitric acid wash had a flexible duct that was long and twisted, which could lead to inefficient vapor capture (Figure 6).

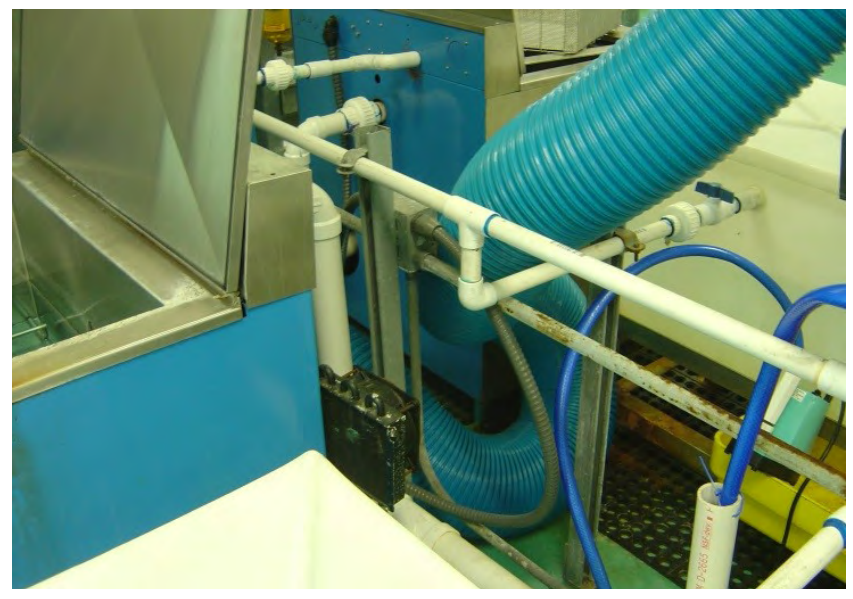

Figure 6. Excess duct in the nitric passivation area. Photo by NIOSH. 


\section{Workplace Observations}

We did not observe mold or signs of water damage in the newly renovated break room. In addition, we discussed with the maintenance staff all the repairs and renovations performed in the break room, which seemed sufficient to address the previously existing mold problem.

The patella-shaping lathe was designed to function as an enclosed machining cabinet; however, the door closer had been overridden so that the operator could manually hold the polymer puck to a spinning support as the lathe shaped it. The employees did this to catch the polymer shavings before they could build up and dislodge the patella (Figure 7). We recommended that a device be developed to hold the puck in place so that the operator would not need to hold it manually. This was done prior to our second visit, and an interlock was installed on the machine to prevent the operator from opening the door to the patella lathe while it was running.

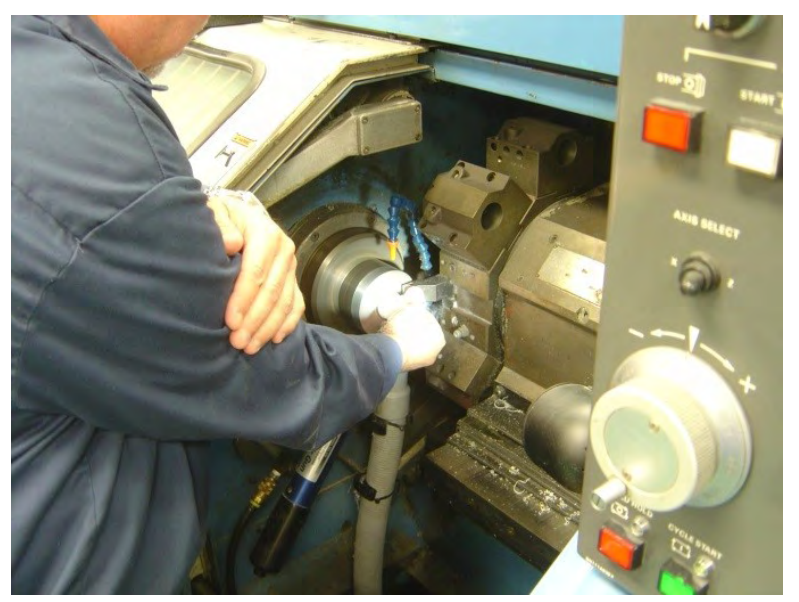

Figure 7. Plastic patella lathe. Photo by NIOSH.

We had the following additional observations:

- One of the cabinets used to sandblast a rough finish on all exposed surfaces of the implants had worn out seals that allowed clouds of dust to be released from the sandblaster.

- Femoral finishing employees were observed using compressed air to blow dust off themselves and the femoral implants.

- Natural rubber latex gloves were used throughout the facility.

- Some employees in the finishing department voluntarily wore an N95 filtering facepiece respirator when polishing parts, but the respirators were not always worn correctly. For example, the metal nose clip was not properly molded to the user's nose, facial hair interfered with a proper face seal, or the bottom neck strap was not worn consistently.

- Some disposable respirators were used beyond the time limit recommended by the manufacturer.

- Employees handled parts covered in MWF with their bare hands. 


\section{Questionnaire}

In June 2013, all 26 employees working in the building completed a questionnaire; 21 had participated in the first site visit interviews. Their average age was 43 (range, 25 to 62 years), and the average number of years worked at the company was 5 (range, 2 months to 20 years). Two of the employees were female. When asked about smoking history, 12 employees reported never smoking, 8 reported being former smokers, and 6 reported they were current smokers.

When asked at what job they spent the most time during the previous 12 months, employees reported the following: metal implant machining $(n=6)$; finishing $(n=13$, including femoral finishing [11], and titanium stem finishing [2]); maintenance $(\mathrm{n}=3)$; passivation $(\mathrm{n}=2)$; laser operating $(n=1)$; and plastic implant machining $(n=1)$. Thirteen employees reported handling used MWF or parts wet with MWF in the past 12 months; eight usually wore gloves when handling used MWF or parts wet with MWF. Seventeen reported polishing or buffing parts in this time period; thirteen usually wore gloves and two sometimes wore gloves when polishing or buffing parts.

Four employees reported having two or more episodes of illness in the 12 months prior to the evaluation, with two or more of the following symptoms: cough, wheeze, shortness of breath, or chest tightness. None had fever or weight loss with these symptoms. Table 5 shows the number of employees who reported specific symptoms within the 12 months prior to our evaluation and the number who reported that the symptom improved away from work.

Table 5. Reported symptoms among 26 employees in the 12 months prior to the evaluation

\begin{tabular}{lcc}
\hline Symptom & $\begin{array}{c}\text { Number of employees } \\
\text { reporting symptom }\end{array}$ & $\begin{array}{c}\text { Number reporting symptoms } \\
\text { improving away from work }\end{array}$ \\
\hline $\begin{array}{l}\text { Nasal congestion, runny nose, } \\
\text { sneezing (not from cold or flu) }\end{array}$ & 12 & 5 \\
Nasal symptoms with itchy, & 6 & Not applicable* $^{*}$ \\
watery eyes & 5 & 3 \\
Wheezing in chest & 4 & Not applicable $^{*}$ \\
Pneumonia or chest flu & 3 & 3 \\
Chest tightness upon waking & 2 & 2 \\
Attack of asthma & &
\end{tabular}

*We did not ask about days away from work for these symptoms. 


\section{Questionnaire Analysis}

We compared the prevalence of symptoms (wheeze, chest tightness, asthma, nasal symptoms, and dermatitis on fingers, hands, wrists, forearms, face, or neck) that improved away from work for employees with MWF exposure in the 12 months prior to the evaluation $(n=13)$ and employees without such exposure $(n=13)$. MWF exposure was not statistically significantly associated with employee reports of skin or respiratory symptoms.

We compared the prevalence of symptoms (wheeze, chest tightness, asthma, nasal symptoms, and dermatitis on fingers, hands, wrists, forearms, face, or neck) that improved away from work for employees with $(n=17)$ and without $(n=9)$ buffing/polishing exposure in the 12 months prior to the evaluation. Buffing or polishing exposure was not statistically significantly associated with employee reports of skin or respiratory symptoms.

When we looked at the 11 employees who reported spending the most time finishing femoral implants in the 12 months prior to our evaluation, we found a statistically significant association $(P<0.01)$ between working as a femoral finisher and having nasal symptoms that improved away from work. We also found a statistically significant association $(P=0.04)$ between working in this job and having dermatitis that improved away from work on the hands, fingers, wrists, forearms, face, or neck (Table 6). All five of the employees reporting dermatitis in the prior 12 months were femoral finishers. Three of the five reported that their dermatitis was better when away from work more than 5 days; two reported that they had not been away from work more than 5 days and therefore could not say whether it was better away from work. Two of the five had dermatitis at the time of the questionnaire. Two employees had seen a doctor for their dermatitis in the 12 months prior to the evaluation. We reviewed medical records for one of these employees and they did not reveal a diagnosis for a skin condition.

Table 6. Number of employees reporting symptoms that improved on days away from work among femoral finishers versus other job groups in the 12 months prior to the evaluation

\begin{tabular}{lccc}
\hline Symptom & $\begin{array}{c}\text { Femoral finishers } \\
(\mathrm{n}=9 \text { to 11) }\end{array}$ & $\begin{array}{c}\text { Other job groups } \\
(\mathrm{n}=15)\end{array}$ & $P$ value \\
\hline $\begin{array}{l}\text { Nasal congestion, runny nose, sneezing } \\
\text { (not from cold or flu) }\end{array}$ & 5 & 0 & $<0.01$ \\
Nasal symptoms with itchy, watery eyes & 3 & 0 & 0.052 \\
$\begin{array}{l}\text { Dermatitis (hands, fingers, wrists, } \\
\text { forearms, face, or neck) }\end{array}$ & 3 & 0 & 0.04 \\
Wheezing in chest & 3 & 0 & 0.06 \\
Chest tightness upon waking & 3 & 0 & 0.06 \\
Attack of asthma & 2 & 0 & 0.17 \\
\hline
\end{tabular}




\section{Biological Exposure Monitoring}

Of the 26 employees, 24 participated in the biological sampling and reported spending the most time during the week of the evaluation at the following jobs: finishing $(n=12)$, metal implant machining $(n=5)$, maintenance $(n=3)$, passivation $(n=2)$, laser operating $(n=1)$, and plastic implant machining $(n=1)$. Fourteen employees reported polishing or buffing parts during the week of our evaluation; 11 of the 14 reported usually wearing gloves during that workweek when polishing or buffing parts. No employees reported participating in hobbies that involved artist paints, glazes, or stains during the week of the evaluation. No employees reported ever having joint replacement surgery with a metal replacement joint. Nine employees reported taking vitamins during the week of our evaluation. We did not see a meaningful difference in urine cobalt levels between employees who did and did not take vitamins.

Three employees had creatinine levels outside the range that ACGIH has suggested is valid ( 0.5 to 3 grams per liter), so we could only accurately interpret the remaining 21 employees' urine cobalt and chromium levels.

\section{Cobalt}

All 21 employees had urine cobalt levels below the ACGIH biological exposure index (BEI () . The median urine concentration of cobalt among the 21 employees was 0.6 micrograms per liter $(\mu \mathrm{g} / \mathrm{L})($ range, $0.3-2.0 \mu \mathrm{g} / \mathrm{L})$, which is well below the BEI for cobalt $(15 \mu \mathrm{g} / \mathrm{L})$.

\section{Chromium}

All 21 employees had urine concentrations of chromium less than $1.0 \mu \mathrm{g} / \mathrm{L}$ (the limit of detection), which is well below the BEI for chromium $(25 \mu \mathrm{g} / \mathrm{L})$.

\section{Comparing Questionnaire, Sampling, and Biomonitoring Data}

\section{Comparing Questionnaire Data with Air and Urine Cobalt Data}

We found that those spending the most time in femoral finishing during the week of our second visit had significantly higher personal air cobalt levels (median $=1.2 \mu \mathrm{g} / \mathrm{m}^{3}$; range, $0.13-7.6 \mu \mathrm{g} / \mathrm{m}^{3} ; \mathrm{n}=8$ ) than those working at other jobs (median $=0.11 \mu \mathrm{g} / \mathrm{m}^{3}$; range, $\left.0.045-2.8 \mu \mathrm{g} / \mathrm{m}^{3} ; \mathrm{n}=9\right)(P=0.03)$. We also compared urine cobalt levels for these two job groups. Femoral finishers had higher median urine cobalt levels (median $=0.95 \mu \mathrm{g} / \mathrm{L}$; range, $0.30-2.0 \mu \mathrm{g} / \mathrm{L} ; \mathrm{n}=8$ ) than those working most of the time in other jobs (median $=0.50 \mu \mathrm{g} / \mathrm{L}$; range, $0.50-1.0 \mu \mathrm{g} / \mathrm{L} ; \mathrm{n}=13)$, but the difference was not statistically significant $(P=0.10)$.

\section{Comparing Urine Cobalt Data with Air Cobalt Data}

The correlation coefficient for the air and urine cobalt measurements was positive $(\mathrm{r}=0.41)$, but it was not statistically significant $(P=0.18)$. 


\section{Noise Monitoring}

Personal noise dosimetry measurements are in Appendix A, Table A8. We measured full-shift noise exposures for all job categories in the building, except the maintenance technicians. OSHA and NIOSH use different criteria for measuring TWA noise exposures (see Appendix B). Although the NIOSH REL for noise is not a legally enforceable noise-exposure limit, it is more protective than the OSHA PEL in preventing hearing loss [NIOSH 1998b]. On the basis of the NIOSH, OSHA AL, and OSHA PEL criteria, the full-shift results measured according to each respective convention were 74 to 96 decibels, A-scale (dBA), 67 to $93 \mathrm{dBA}$, and 67 to $93 \mathrm{dBA}$. Twelve of the 17 noise exposures exceeded the NIOSH REL, 6 exceeded the OSHA AL, and 1 exceeded the OSHA PEL. The job titles that were over the NIOSH REL included the femoral finishers working at the buffing and polishing stations, titanium finishers, the nitric passivation operators, and the femoral finishers working on the tumbler polishing stations. A cobalt polishing/buffing operator had the highest noise exposure ( $93 \mathrm{dBA}$ on the basis of OSHA criteria, or $96 \mathrm{dBA}$ on the basis of NIOSH criteria, averaged over an 8-hour work shift). The lowest noise levels were measured on the drag finishers and the machinists.

Insert-type hearing protectors (earplugs) were available for use, but we observed very few employees using them. Some of the employees using these hearing protectors did not insert them deeply enough in the ear canal, a deficiency which can reduce the noise attenuation. None of the employees were enrolled in a hearing conservation program, nor did they have periodic training and annual audiometric tests.

\section{Discussion}

Our evaluation found employee exposures to MWF, cobalt, chromium, and hexavalent chromium. Each of these substances can result in nasal symptoms and contact dermatitis, both irritant and allergic [Gheysens et al. 1985; Burton et al. 2012; Walters et al. 2012]. The results of our exposure assessment, medical interviews, and analysis of the health questionnaire suggest that cobalt dust exposure was a likely cause of nasal, respiratory, and skin symptoms reported by femoral finishers. We found one high airborne cobalt dust level at the box polishing station during our first visit and a statistically significant relationship between working as a femoral finisher (finishing cobalt-chromium parts) and having workrelated nasal and skin symptoms. One limitation of our data is that our sampling results do not reflect the variability in exposures that occur over time, and therefore, exposures on different days could be higher or lower. On our second site visit, we found low air and urine cobalt levels among employees indicating low overall exposure to cobalt. Despite the low cobalt levels, caution is still needed because very small levels of cobalt exposure in sensitized individuals could lead to skin allergy or an asthma-like allergy.

We found that the air and urine cobalt results were only weakly correlated. Although employees with higher air cobalt results did tend to have higher values of urine cobalt, knowing the air sampling results alone do not give enough information to predict their urine cobalt levels accurately. The small number of air and urine samples collected and the short sampling time period could have limited our statistical findings. In addition, skin exposure from contaminated surfaces, and ingestion of cobalt through contaminated skin, food, and 
drink, possibly contributed to cobalt exposure among all production employees.

Employees can be exposed to hexavalent chromium as a by-product of heat-producing tasks such as welding, sanding, or grinding on products containing chromium. The personal and area air sampling results, although below OELs, indicate that finishing cobalt-chromium femorals resulted in airborne hexavalent chromium. The personal air sample results for hexavalent chromium for the femoral finisher doing box polishing was $0.14 \mu \mathrm{g} / \mathrm{m}^{3}$, more than half the NIOSH REL of $0.2 \mu \mathrm{g} / \mathrm{m}^{3}$ [NIOSH 2013]. Hexavalent chromium is carcinogenic to humans and is associated with cancer of the lung, nose, and nasal sinuses [IARC 2012; NIOSH 2013]. A 2015 study suggests that hexavalent chromium is associated with an increased risk for stomach cancer [Welling et al. 2015]. Occupational hexavalent chromium exposure has also been associated with irritation or damage to the nose, throat, lungs, eyes, and skin, including allergic contact dermatitis.

We found low air concentrations of MWF but no association between employee respiratory or skin symptoms and working as a machinist, indicating that MWF exposures do not appear to be resulting in health problems at this facility. However, machinists could have cobalt and chromium exposure from the tungsten carbide machining tools. Studies have found that machining with these tools can potentially leach cobalt and chromium into MWFs [Sjogren et al. 1980; Walters et al. 2012], which can be inhaled via MWF mist or contacted through skin contamination. Our results for cobalt and chromium in used MWF samples were consistent with this finding. Many types of MWFs contain potential skin allergens and irritants. In addition, heavy metals such as cobalt can be absorbed into the fluids and transferred to the employee's skin. Persons who are sensitized to chromium or cobalt may experience an allergic reaction if these metals touch the skin or are inhaled.

We found aluminum in the air at very low concentrations. Because the air concentrations of aluminum were very low, it is unlikely that employees would develop health problems associated with airborne aluminum exposure (Appendix B).

Aluminum, chromium, cobalt, and titanium were found on non-production area surfaces. This finding indicates that metals were migrating out of the production area and onto surfaces throughout the facility, including the break room, refrigerator, and conference room where we held interviews. Although there are no OELs for the substances we sampled on surfaces, the presence of these metals outside the production area could contribute to employee exposure through ingestion. The presence of these metals on surfaces contributes to overall exposure and can lead to sensitization. In persons sensitized to these metals, skin contact with the offending metal can result in allergic contact dermatitis.

Some employees wore latex gloves. Latex can cause irritant contact dermatitis, allergic contact dermatitis, and immediate hypersensitivity [NIOSH 1997]. Because of the severity of symptoms that sensitized individuals my experience, latex should be avoided in most occupational settings.

We found noise exposures above the NIOSH REL among cobalt polishers/grinders, titanium stem grinders, nitric passivation operators, and tumbler/polishers; some noise exposures were above the OSHA PEL and AL. The company did not have a hearing conservation program 
and few employees wore hearing protection. Engineering controls are the most effective in preventing noise induced hearing loss among employees and reduce the need for employees to wear hearing protection. Because effective noise engineering controls can be challenging to design and implement, noise reduction should be considered as part of an overall longterm strategy. For example, when equipment is replaced, the amount of noise generated by the new equipment should be considered in the purchasing decision.

\section{Conclusions}

We determined that a health hazard from airborne cobalt exposure existed in the femoral finishing department box polishing station. However, improvements made to the finishing department's local exhaust ventilation system helped lower airborne cobalt levels. We also determined that femoral finishers working at the box polish station had exposure to airborne hexavalent chromium, an human carcinogen, up to half of the NIOSH REL. Cobalt, chromium, and aluminum surface contamination in the employee break room posed a risk to employees from skin contact and ingestion, both possibly leading to sensitization. Exposure to MWFs and metal contaminants present in the fluids can also result in skin and respiratory sensitization though we did not find evidence of this in our evaluation. We found that employees were overexposed to noise in the polishing and buffing areas and in the nitric passivation room, but no hearing conservation program was in place. We did not find evidence of mold growth or water damage in areas where mold growth had been found previously.

\section{Recommendations}

On the basis of our findings, we recommend the actions listed below. We encourage the medical implant manufacturer to use a labor-management health and safety committee or working group to discuss our recommendations and develop an action plan. Those involved in the work can best set priorities and assess the feasibility of our recommendations for the specific situation at the facility.

Our recommendations are based on an approach known as the hierarchy of controls. This approach groups actions by their likely effectiveness in reducing or removing hazards. In most cases, the preferred approach is to eliminate hazardous materials or processes and install engineering controls to reduce exposure or shield employees. Until such controls are in place, or if they are not effective or feasible, administrative measures and personal protective equipment may be needed.

\section{Engineering Controls}

Engineering controls reduce employees' exposures by removing the hazard from the process or by placing a barrier between the hazard and the employee. Engineering controls protect employees effectively without placing primary responsibility of implementation on the employee.

1. Install engineering controls at noisy equipment in the nitric passivation room and buffing/polishing area to reduce noise exposures. Consult with an acoustic engineer for specific guidance on noise control strategies. 
2. Optimize the local exhaust ventilation system over the nitric acid passivation tank by installing a short, hard duct; removing unnecessary ductwork; and eliminating $90^{\circ}$ turns. Re-evaluate the ventilation system performance after changes are made.

3. Perform periodic preventive maintenance on all local exhaust ventilation units.

4. Replace the worn-out gaskets on the older sandblasting hoods.

5. Design a holding tool for the dip seal process so that employees do not have to use their fingers to dip the parts in hot liquid.

\section{Administrative Controls}

Administrative controls are employer-dictated work practices and policies to reduce or prevent hazardous exposures. Their effectiveness depends on employer commitment and employee acceptance. Regular monitoring and reinforcement are necessary to ensure that the policies and procedures are followed consistently.

1. Implement a hearing conservation program for all employees who work in the buffing, polishing, and grinding area and those who work in the nitric passivation room. The program should include annual audiometric testing and training. More information on establishing a hearing conservation program can be found at http://www.cdc.gov/ niosh/docs/98-126/pdfs/98-126.pdf, http://www.osha.gov/dts/osta/otm/noise/hcp/ index.html, and http://www.osha.gov/Publications/osha3074.pdf.

2. Improve hazard communication training to include the hazards and potential health effects associated with cobalt, chromium, solvents, and other chemical exposures in the workplace. Emphasize proper work practices, hand hygiene, and skin protection techniques that prevent exposure to these substances.

3. Develop a training program on the proper handling and use of MWF and on the hazards and potential health effects associated with MWF exposure. Guidelines for MWF training are included in the 1998 NIOSH document What You Need to Know About Occupational Exposure to Metalworking Fluids, available at: http://www.cdc. gov/niosh/pdfs/98-116.pdf.

4. Stop employees from using compressed air to clean work clothing. If needed, vacuum dust from work clothing and parts using a high-efficiency particulate arrestance air filter vacuum with nozzle.

5. Collect additional personal air samples for hexavalent chromium to further characterize worker exposures and to determine if exposure controls and medical monitoring programs should be implemented.

6. Conduct periodic air sampling for cobalt around the box polishing station to ensure that concentrations remain below OELs.

7. Improve housekeeping procedures in nonproduction areas and encourage personal hygiene such as hand washing after glove removal and prior to eating and drinking to reduce the risk of ingesting metals. 
8. Encourage employees to report potential work-related health conditions to their supervisor. Employees with persistent symptoms should be evaluated by an occupational medicine physician or a medical provider specializing in workplace illnesses. The Association of Occupational and Environmental Clinics has an online directory of such providers at http://www.aoec.org/directory.htm.

9. Look for health problem or injury trends reported in company injury and illness logs that may be related to particular job duties, work materials, machines, or areas of the facility. Evaluate areas or jobs that show an increase in injuries or health problems and develop an intervention to reduce exposures.

\section{Personal Protective Equipment}

Personal protective equipment is the least effective means for controlling hazardous exposures. Proper use of personal protective equipment requires a comprehensive program and a high level of employee involvement and commitment. The right personal protective equipment must be chosen for each hazard. Supporting programs such as training, changeout schedules, and medical assessment may be needed. Personal protective equipment should not be the sole method for controlling hazardous exposures; it should be used until effective engineering and administrative controls are in place.

1. Provide nitrile gloves instead of natural rubber latex gloves to protect employees' skin from dermal exposures, including MWFs, parts covered with MWF, and metal dusts. Train employees on proper glove wear and on visual signs that the glove material is worn out, so that they recognize when they need new gloves. Additional information on the occupational hazards associated with latex exposure can be found in the NIOSH Alert Preventing Allergic Reactions to Natural Rubber Latex in the Workplace, available at http://www.cdc.gov/niosh/docs/97-135/.

2. Require employees to wear hearing protection when buffing and polishing parts and when they are in the nitric passivation room until engineering controls are demonstrated to reduce noise exposures below the NIOSH REL.

3. Encourage employees who voluntarily use disposable filtering facepiece respirators to wear them properly. Guidelines for putting on and taking off a disposable respirator are available at http://www.cdc.gov/niosh/docs/2010-133/pdfs/2010-133.pdf. 


\section{Appendix A: Tables}

Table A1. Hexavalent chromium concentrations in personal air samples, February 2013

\begin{tabular}{lccc}
\hline Job title & Job task & Minutes sampled & Concentration $\left(\mu \mathrm{g} / \mathrm{m}^{3}\right)$ \\
\hline Femoral finisher & Box polishing & 431 & 0.14 \\
Femoral finisher & Finisher III, first polish & 446 & $(0.010)^{*}$ \\
Femoral finisher & Polish/buff & 431 & ND \\
Femoral finisher & Trim and blast (hand tool) & 451 & $(0.030)$ \\
\hline NIOSH REL & & - & 0.2 \\
OSHA PEL & & - & 5 \\
ACGIH TLV & & - & 10 \\
\hline
\end{tabular}

The MDC was $0.01 \mu \mathrm{g} / \mathrm{m}^{3}$ and the MQC was $0.050 \mu \mathrm{g} / \mathrm{m}^{3}$ on the basis of an average sample duration of 456 minutes and sample volume of 912 liters.

*Values in parentheses are between the MDC and the MQC, meaning there is more uncertainty associated with these results.

Table A2. Hexavalent chromium concentration in area air samples, February 2013

\begin{tabular}{lcc}
\hline Area & Minutes sampled & Concentration $\left(\mu \mathrm{g} / \mathrm{m}^{3}\right)$ \\
\hline Cobalt chrome, hand tool, trim and blast & 425 & $\mathrm{ND}$ \\
Cobalt chrome, work in progress cans & 426 & $\mathrm{ND}$ \\
Titanium, stem cell grind & 427 & $\mathrm{ND}$ \\
Between box polishing stations & 525 & $(0.02)^{*}$ \\
Trim and blast half, box polishing & 436 & 0.081 \\
Cobalt/chrome by sandblaster & 508 & $\mathrm{ND}$ \\
By belt sander in cobalt/chrome & 512 & $\mathrm{ND}$ \\
\hline
\end{tabular}

The MDC was $0.01 \mu \mathrm{g} / \mathrm{m}^{3}$ and the MQC was $0.05 \mu \mathrm{g} / \mathrm{m}^{3}$ on the basis of an average sample duration of 456 minutes and sample volume of 912 liters.

*Values in parentheses are between the MDC and the MQC, meaning there is more uncertainty associated with these results. 
Table A3. MWFs in air, measured as total particulate fraction in personal samples, February 2013

\begin{tabular}{lcc}
\hline Job title & Minutes sampled & Concentration $\left(\mu \mathrm{g} / \mathrm{m}^{3}\right)$ \\
\hline Machinist, grinder operator & 443 & $(34)^{*}$ \\
CNC lathe grinder operator & 445 & $\mathrm{ND}$ \\
Maintenance technician & 450 & $\mathrm{ND}$ \\
\hline NIOSH REL & - & 500 \\
\hline
\end{tabular}

The MDC was $24 \mu \mathrm{g} / \mathrm{m}^{3}$ and the MQC was $120 \mu \mathrm{g} / \mathrm{m}^{3}$ on the basis of an average sample duration of 420 minutes and sample volume of 840 liters.

*Values in parentheses are between the MDC and the MQC, meaning there is more uncertainty associated with these results.

Table A4. MWFs in air, measured as total particulate fraction in area samples, February 2013

\begin{tabular}{lcc}
\hline Area & Minutes sampled & Concentration $\left(\mu \mathrm{g} / \mathrm{m}^{3}\right)$ \\
\hline Grinder number 1 & 259 & $(38)^{*}$ \\
Haas grinder & 430 & $(23)$ \\
Behind the grinders, by door & 425 & $\mathrm{ND}$ \\
Grinder 1, by operator access point & 437 & $(34)$ \\
Backside of grinder 3 & 439 & $\mathrm{ND}$ \\
Grinder 3, by operator & 438 & $(23)$ \\
Haas grinder & 437 & $\mathrm{ND}$ \\
\hline
\end{tabular}

The MDC was $24 \mu \mathrm{g} / \mathrm{m}^{3}$ and the MQC was $120 \mu \mathrm{g} / \mathrm{m}^{3}$ on the basis of an average sample duration of 409 minutes and sample volume of 840 liters.

*Values in parentheses are between the MDC and the MQC, meaning there is more uncertainty associated with these results. 
Table A5. Metal concentrations in personal air samples, June 2013

\begin{tabular}{|c|c|c|c|c|c|c|}
\hline Job Title & Job Task & $\begin{array}{l}\text { Minutes } \\
\text { sampled }\end{array}$ & $\begin{array}{c}\text { Aluminum } \\
\left(\mu \mathrm{g} / \mathrm{m}^{3}\right)\end{array}$ & $\begin{array}{l}\text { Chromium } \\
\left(\mu \mathrm{g} / \mathrm{m}^{3}\right)\end{array}$ & $\begin{array}{c}\text { Cobalt } \\
\left(\mu \mathrm{g} / \mathrm{m}^{3}\right)\end{array}$ & $\begin{array}{l}\text { Titanium } \\
\left(\mu \mathrm{g} / \mathrm{m}^{3}\right)\end{array}$ \\
\hline \multicolumn{7}{|l|}{ Day 1: First shift } \\
\hline Femoral finisher \#1 & Drag finish & 443 & 2.6 & ND & 0.17 & $(0.020)^{*}$ \\
\hline $\begin{array}{l}\text { Titanium stem } \\
\text { finisher }\end{array}$ & Titanium polish & 354 & ND & $(0.99)$ & 2.8 & 1.2 \\
\hline Femoral finisher \#2 & Box polishing & 463 & ND & $(0.60)$ & 1.3 & 0.35 \\
\hline Femoral finisher \#3 & Mask and blast & 439 & $(1.3)$ & $(0.65)$ & 1.1 & 0.081 \\
\hline Metal machinist \#1 & $\begin{array}{l}\text { Machining/ } \\
\text { grinding }\end{array}$ & 458 & ND & ND & $(0.045)$ & ND \\
\hline Femoral finisher \#4 & Tumbler/polish & 456 & ND & ND & 0.11 & 0.19 \\
\hline \multicolumn{7}{|l|}{ Day 1: Second shift } \\
\hline Femoral finisher \#1 & 1st cobalt polish & 466 & 4.5 & 2.7 & 7.6 & 0.055 \\
\hline Femoral finisher \#2 & 2nd cobalt polish & 470 & 3.6 & 2.2 & 5.0 & 0.10 \\
\hline Metal machinist \#1 & $\begin{array}{l}\text { Machining/ } \\
\text { grinding }\end{array}$ & 455 & ND & ND & $(0.081)$ & ND \\
\hline Femoral finisher \#3 & Buffing/polishing & 464 & $(1.1)$ & $(0.67)$ & 1.3 & $(0.023)$ \\
\hline $\begin{array}{l}\text { Titanium stem } \\
\text { finisher }\end{array}$ & $\begin{array}{l}\text { Titanium } \\
\text { polishing }\end{array}$ & 445 & ND & ND & 0.19 & 1.9 \\
\hline Plastic machinist & $\begin{array}{l}\text { Implant } \\
\text { machinist }\end{array}$ & 424 & ND & ND & 0.11 & $(0.012)$ \\
\hline \multicolumn{7}{|l|}{ Day 2: First shift } \\
\hline Metal machinist \#1 & $\begin{array}{l}\text { Machining/ } \\
\text { grinding }\end{array}$ & 436 & ND & ND & $(0.67)$ & ND \\
\hline $\begin{array}{l}\text { Titanium stem } \\
\text { finisher }\end{array}$ & Titanium polish & 446 & ND & ND & $(0.07)$ & 0.49 \\
\hline Femoral finisher \#1 & Drag finish & 430 & ND & ND & 0.13 & 0.020 \\
\hline Femoral finisher \#4 & Tumble/polish & 438 & ND & ND & $(0.060)$ & 0.050 \\
\hline Femoral finisher \#3 & Mask and blast & 378 & $(1.5)$ & ND & 0.72 & 0.36 \\
\hline OSHA PEL & & - & 15,000 & 1,000 & 100 & $\begin{array}{c}\text { Not } \\
\text { applicable }\end{array}$ \\
\hline NIOSH REL & & - & 10,000 & 500 & 50 & $\begin{array}{c}\text { Not } \\
\text { applicable }\end{array}$ \\
\hline ACGIH TLV & & - & $1,000 \dagger$ & 500 & 20 & $\begin{array}{c}\text { Not } \\
\text { applicable }\end{array}$ \\
\hline \multicolumn{2}{|c|}{ Minimum detectable concentration } & - & 0.7 & 0.4 & 0.04 & 0.01 \\
\hline \multicolumn{2}{|c|}{ Minimum quantifiable concentration } & - & 2 & 1 & 0.1 & 0.03 \\
\hline
\end{tabular}

The MDC and MQC were determined on the basis of an average sample duration of 432 minutes and sample volume of 864 liters.

*Values in parentheses are between the MDC and the MQC, meaning there is more uncertainty associated with these results.

†Respirable fraction of the sample; we measured the total particulate fraction which includes respirable and other inhalable particles. 
Table A6. Metals found in surface wipe samples, February 2013

\begin{tabular}{lccc}
\hline Areas & $\begin{array}{c}\text { Chromium } \\
\left(\mu \mathrm{g} / 100 \mathrm{~cm}^{2}\right)\end{array}$ & $\begin{array}{c}\text { Cobalt } \\
\left(\mu \mathrm{g} / 100 \mathrm{~cm}^{2}\right)\end{array}$ & $\begin{array}{c}\text { Titanium } \\
\left(\mu \mathrm{g} / 100 \mathrm{~cm}^{2}\right)\end{array}$ \\
\hline Non-production areas & 0.3 & 0.61 & 0.074 \\
Interview room table & 0.078 & $\mathrm{ND}$ & 0.019 \\
Conference room table & 0.14 & 0.23 & 0.022 \\
Carpet in main hall & 0.99 & 2.3 & 0.12 \\
Doorknob from production* & 9.4 & 22 & 0.26 \\
Floor in front of men's restroom & 0.49 & 0.92 & 0.098 \\
Maintenance tech's workstation & 0.72 & 1.6 & 0.043 \\
Maintenance tech's workstation & 0.23 & 0.27 & $\mathrm{ND}$ \\
Break room microwave & 3.1 & 7 & 0.22 \\
Break room floor & 2.3 & 1 & 0.35 \\
Break room refrigerator handle & 0.12 & 0.22 & 0.087 \\
Break room table & 2.9 & 5.1 & 3.1 \\
Break room door handle* & & & 1.1 \\
\hline Production Areas & 76 & 180 & 7.5 \\
Box Polishing station & 320 & 760 & 170 \\
Cobalt/chromium polish station & 95 & 210 & 0.007 \\
\hline Titanium polish workstation & 0.4 & 0.06 & \\
\hline Limit of detection & & & \\
\hline
\end{tabular}

*These were irregular surfaces, and $100 \mathrm{~cm}^{2}$ was estimated

Table A7. Metals found in surface wipe samples, June 2013

\begin{tabular}{|c|c|c|c|c|}
\hline Areas & $\begin{array}{l}\text { Aluminum } \\
\left(\mu \mathrm{g} / 100 \mathrm{~cm}^{2}\right)\end{array}$ & $\begin{array}{l}\text { Chromium } \\
\left(\mu \mathrm{g} / 100 \mathrm{~cm}^{2}\right)\end{array}$ & $\begin{array}{c}\text { Cobalt } \\
\left(\mu \mathrm{g} / 100 \mathrm{~cm}^{2}\right)\end{array}$ & $\begin{array}{c}\text { Titanium } \\
\left(\mu \mathrm{g} / 100 \mathrm{~cm}^{2}\right)\end{array}$ \\
\hline \multicolumn{5}{|l|}{ Non-production areas } \\
\hline Break room table, after lunch & 1.2 & 0.1 & 0.13 & 0.04 \\
\hline Door into break room, on wood & 5.3 & 2.5 & 6.3 & 0.21 \\
\hline $\begin{array}{l}\text { Break room counter, by coffee } \\
\text { maker }\end{array}$ & 2 & 5 & 11 & 0.23 \\
\hline Door handle to break area* & 12 & 0.87 & 1.9 & 0.22 \\
\hline Water fountain* & 1.7 & 0.21 & 0.43 & ND \\
\hline Exit button from production area* & ND & 4.3 & 2.5 & 0.029 \\
\hline Top stair to the break area & 2.2 & 4.8 & 11 & 0.08 \\
\hline \multicolumn{5}{|l|}{ Production areas } \\
\hline Floor in front of patella area & 2 & 2.3 & 5.3 & 0.1 \\
\hline Inside gloves at mask and blast ${ }^{\star}$ & 1.7 & 2.6 & 6.1 & 0.053 \\
\hline Inside gloves at titanium stem grind ${ }^{*}$ & ND & 1.2 & 2.7 & 0.27 \\
\hline Haas "C" machinist mouse* & 2.6 & 3.2 & 7.1 & 0.14 \\
\hline Limit of detection & 1.0 & 0.03 & 0.06 & 0.02 \\
\hline
\end{tabular}

*These were irregular surfaces, and $100 \mathrm{~cm}^{2}$ was estimated 
Table A8. Noise dosimeter results by job task, June 2013

\begin{tabular}{|c|c|c|c|c|c|}
\hline Job titles & Job tasks & $\begin{array}{l}\text { OSHAAL } \\
\text { (dBA) }\end{array}$ & $\begin{array}{l}\text { OSHA PEL } \\
(\mathrm{dBA})\end{array}$ & $\begin{array}{l}\text { NIOSH REL } \\
(\mathrm{dBA})\end{array}$ & $\begin{array}{l}\text { Sample duration } \\
\text { (hours:minutes) }\end{array}$ \\
\hline Femoral finisher \#1 & Drag finishing & 70 & 69 & 78 & $7 \mathrm{~h}: 24 \mathrm{~min}$ \\
\hline Femoral finisher \#2 & Drag finishing & 75 & 74 & 80 & $7 \mathrm{~h}: 10 \mathrm{~min}$ \\
\hline Femoral finisher \#3 & Box polishing & 89 & 88 & 90 & $7 \mathrm{~h}: 43 \mathrm{~min}$ \\
\hline Femoral finisher \#4 & $\begin{array}{l}\text { Mask and } \\
\text { blasting }\end{array}$ & 82 & 82 & 87 & $7 \mathrm{~h}: 20 \mathrm{~min}$ \\
\hline Femoral finisher \#5 & $\begin{array}{l}\text { Mask and } \\
\text { blasting }\end{array}$ & 83 & 82 & 88 & $6 \mathrm{~h}: 16 \mathrm{~min}$ \\
\hline Femoral finisher \#6 & $\begin{array}{l}\text { Tumbler } \\
\text { polishing }\end{array}$ & 87 & 86 & 91 & $7 \mathrm{~h}: 37 \mathrm{~min}$ \\
\hline Femoral finisher \#7 & $\begin{array}{l}\text { Tumbler } \\
\text { polishing }\end{array}$ & 84 & 83 & 89 & $7 \mathrm{~h}: 18 \mathrm{~min}$ \\
\hline Femoral finisher \#8 & $\begin{array}{l}\text { Hand cobalt } \\
\text { polishing }\end{array}$ & 85 & 85 & 87 & $7 \mathrm{~h}: 24 \mathrm{~min}$ \\
\hline Femoral finisher \#9 & $\begin{array}{l}\text { Cobalt } \\
\text { polishing }\end{array}$ & 81 & 79 & 87 & $5 \mathrm{~h}: 48 \mathrm{~min}$ \\
\hline Femoral finisher \#10 & $\begin{array}{c}\text { Cobalt } \\
\text { polishing }\end{array}$ & 93 & 93 & 96 & $7 \mathrm{~h}: 52 \mathrm{~min}$ \\
\hline Metal machinist \#1 & $\begin{array}{l}\text { Femoral } \\
\text { machining }\end{array}$ & 75 & 75 & 80 & $7 \mathrm{~h}: 39 \mathrm{~min}$ \\
\hline Metal machinist \#2 & $\begin{array}{l}\text { Femoral } \\
\text { machining }\end{array}$ & 67 & 67 & 74 & $7 \mathrm{~h}: 29 \min$ \\
\hline Titanium finisher \#1 & $\begin{array}{l}\text { Titanium } \\
\text { stem } \\
\text { polishing }\end{array}$ & 87 & 87 & 89 & $7 \mathrm{~h}: 51 \mathrm{~min}$ \\
\hline Titanium finisher \#2 & $\begin{array}{l}\text { Titanium } \\
\text { stem } \\
\text { polishing }\end{array}$ & 81 & 80 & 84 & $7 \mathrm{~h}: 25 \min$ \\
\hline $\begin{array}{l}\text { Nitric passivation } \\
\text { operator \#1 }\end{array}$ & $\begin{array}{c}\text { Nitric } \\
\text { passivation }\end{array}$ & 84 & 84 & 91 & $7 \mathrm{~h}: 35 \mathrm{~min}$ \\
\hline $\begin{array}{l}\text { Nitric passivation } \\
\text { operator \#2 }\end{array}$ & $\begin{array}{c}\text { Nitric } \\
\text { passivation }\end{array}$ & 80 & 79 & 86 & $7 \mathrm{~h}: 42 \min$ \\
\hline $\begin{array}{l}\text { Nitric passivation } \\
\text { operator \#3 }\end{array}$ & $\begin{array}{c}\text { Nitric } \\
\text { passivation }\end{array}$ & 85 & 85 & 93 & $7 \mathrm{~h}: 05 \mathrm{~min}$ \\
\hline Exposure limits & & 85 & 90 & 85 & \\
\hline
\end{tabular}

Note: Areas in grey indicate an overexposure 


\section{Appendix B: Occupational Exposure Limits and Health Effects}

NIOSH investigators refer to mandatory (legally enforceable) and recommended OELs for chemical, physical, and biological agents when evaluating workplace hazards. OELs have been developed by federal agencies and safety and health organizations to prevent adverse health effects from workplace exposures. Generally, OELs suggest levels of exposure that most employees may be exposed to for up to 10 hours per day, 40 hours per week, for a working lifetime, without experiencing adverse health effects. However, not all employees will be protected if their exposures are maintained below these levels. Some may have adverse health effects because of individual susceptibility, a pre-existing medical condition, or a hypersensitivity (allergy). In addition, some hazardous substances act in combination with other exposures, with the general environment, or with medications or personal habits of the employee to produce adverse health effects. Most OELs address airborne exposures, but some substances can be absorbed directly through the skin and mucous membranes.

Most OELs are expressed as a TWA exposure. A TWA refers to the average exposure during a normal 8- to 10-hour workday. Some chemical substances and physical agents have recommended short term exposure limits (STELs) or ceiling values. Unless otherwise noted, the STEL is a 15-minute TWA exposure. It should not be exceeded at any time during a workday. The ceiling limit should not be exceeded at any time.

In the United States, OELs have been established by federal agencies, professional organizations, state and local governments, and other entities. Some OELs are legally enforceable limits; others are recommendations.

- The U.S. Department of Labor OSHA PELs (29 CFR 1910 [general industry]; 29 CFR 1926 [construction industry]; and 29 CFR 1917 [maritime industry]) are legal limits. These limits are enforceable in workplaces covered under the Occupational Safety and Health Act of 1970.

- NIOSH RELs are recommendations based on a critical review of the scientific and technical information and the adequacy of methods to identify and control the hazard. NIOSH RELs are published in the NIOSH Pocket Guide to Chemical Hazards [NIOSH 2010]. NIOSH also recommends risk management practices (such as engineering controls, safe work practices, employee education/training, personal protective equipment, and exposure and medical monitoring) to minimize the risk of exposure and adverse health effects.

- Other OELs commonly used and cited in the United States include the TLVs, which are recommended by ACGIH, a professional organization, and the workplace environmental exposure levels (WEELs), which are recommended by the American Industrial Hygiene Association, another professional organization. The TLVs and WEELs are developed by committee members of these associations from a review of the published, peer-reviewed literature. These OELs are not consensus standards. TLVs are considered voluntary exposure guidelines for use by industrial hygienists and others 
trained in this discipline "to assist in the control of health hazards" [ACGIH 2015]. WEELs have been established for some chemicals "when no other legal or authoritative limits exist" [AIHA 2015].

The ACGIH BEI is a concentration below which nearly all workers will not experience adverse health effects. They are correlated with TLVs, i.e., air levels of chemicals. BEIs are set by ACGIH and are voluntary guidelines for making decisions regarding safe levels of exposure to various chemical substances and physical agents found in the workplace.

Outside the United States, OELs have been established by various agencies and organizations and include legal and recommended limits. The Institut für Arbeitsschutz der Deutschen Gesetzlichen Unfallversicherung (Institute for Occupational Safety and Health of the German Social Accident Insurance) maintains a database of international OELs from European Union member states, Canada (Québec), Japan, Switzerland, and the United States. The database, available at http://www.dguv.de/ifa/Gefahrstoffdatenbanken/GESTIS-InternationaleGrenzwerte-für-chemische-Substanzen-limit-values-for-chemical-agents/index-2.jsp, contains international limits for more than 1,500 hazardous substances and is updated periodically.

OSHA requires an employer to furnish employees a place of employment free from recognized hazards that cause or are likely to cause death or serious physical harm [Occupational Safety and Health Act of 1970 (Public Law 91-596, sec. 5(a)(1))]. This is true in the absence of a specific OEL. It also is important to keep in mind that OELs may not reflect current health-based information.

When multiple OELs exist for a substance or agent, NIOSH investigators generally encourage employers to use the lowest OEL when making risk assessment and risk management decisions. NIOSH investigators also encourage use of the hierarchy of controls approach to eliminate or minimize workplace hazards. This includes, in order of preference, the use of (1) substitution or elimination of the hazardous agent, (2) engineering controls (such as local exhaust ventilation, process enclosure, and dilution ventilation), (3) administrative controls (such as employee training, work practice changes, medical surveillance, and limiting time of exposure), and (4) personal protective equipment (such as respiratory protection, gloves, eye protection, and hearing protection). Control banding, a qualitative risk assessment and risk management tool, is a complementary approach to protecting employee health. Control banding focuses on how broad categories of risk should be managed. Information on control banding is available at http://www.cdc.gov/niosh/ topics/ctrlbanding/. This approach can be applied in situations where OELs have not been established, or it can be used to supplement existing OELs.

Below we provide the OELs for cobalt, chromium, hexavalent chromium, MWF, and aluminum (Table B1), as well as a discussion of their potential health effects. There are no OELs and limited information on health effects from exposure to titanium metal. OELs for titanium dioxide exist, but this compound has properties and effects that differ from titanium metal and is beyond the scope of this evaluation. 
Table B1. Occupational exposure limits for metals

\begin{tabular}{lccc}
\hline Substance & $\begin{array}{c}\text { OSHA PEL } \\
\left(\mu \mathrm{g} / \mathrm{m}^{3}\right)\end{array}$ & $\begin{array}{c}\mathrm{NIOSH} \text { REL } \\
\left(\mu \mathrm{g} / \mathrm{m}^{3}\right)\end{array}$ & $\begin{array}{c}\text { ACGIH TLV } \\
\left(\mu \mathrm{g} / \mathrm{m}^{3}\right)\end{array}$ \\
\hline Cobalt & 100 & 50 & 20 \\
Total chromium & 500 & 500 & 500 \\
Hexavalent chromium & 5.0 & 0.2 & $10^{*}$ \\
MWF & 500 & $500 \dagger$ & - \\
Aluminum & 15,000 & 10,000 & $1,000(\mathrm{R})$ \\
\hline
\end{tabular}

$(R)=$ respirable fraction only. We measured the total aerosol fraction.

*As insoluble hexavalent chromium compounds

†For up to 10 hours per day during a 40-hour workweek as the total particulate fraction

\section{Cobalt}

Cobalt is an essential element and is present in the human diet in tiny amounts. Dietary cobalt exposure is unlikely to affect occupational urine biomonitoring measurements. Occupational cobalt exposure comes from metallurgical industries where metals containing cobalt are processed by grinding, drilling, and sanding. Cobalt is used as a pigment in some artist supplies. Patients who have undergone total hip replacement have been shown to have urine cobalt levels exceeding the upper normal value of the BEI [ACGIH 2001]. Vitamins may contain vitamin B12, or cyanocobalamin, which contains cobalt. Persons taking multivitamin pills containing cobalt have been shown to have increased cobalt excretion in the urine [ACGIH 2001]. In the general population of Western countries, the average concentration of cobalt in adult urine ranges between 0.1 and $2 \mu \mathrm{g} / \mathrm{L}$ [ACGIH 2001]. The BEI for end-of-shift, end-of-workweek cobalt in urine is $15 \mu \mathrm{g} / \mathrm{L}$. OSHA does not have a legal requirement for levels of urine cobalt.

Cobalt exposure has been associated with the development of occupational asthma, pneumoconiosis (a restrictive lung disease caused from inhaling dust), heart problems, and allergic contact dermatitis [Sjogren et al. 1980; Gheysens et al. 1985; Walters et al. 2012]. Some studies have shown that low levels of cobalt can lead to a decrease in lung function [Rehfisch et al. 2015]. Other study findings indicate that skin exposure to cobalt and other sensitizing chemicals may lead to an asthma-like response [Sjogrens et al. 1980; Arrandale et al. 2012]. About $90 \%$ of absorbed cobalt is eliminated rapidly within a few days; about $10 \%$ is eliminated with a biological half-life of about 2 years [ACGIH 2001]. No information was found on the dermal absorption of cobalt, but skin contact with cobalt may result in a hypersensitivity to cobalt in a small percentage of occupationally exposed persons.

\section{Chromium}

Chromium is most often used as an alloy (ferrochrome) in stainless steel and in chrome plating. In addition, chromium is used in the pigment and dye, tanning, and glassmaking industries. Exposure to chromium can cause eye, nose, throat, and skin irritation, and may cause skin allergy [NIOSH 2010]. In the general population of Western countries, the average 
concentration of chromium in the urine ranges from 0.24 to $1.8 \mu \mathrm{g} / \mathrm{L}$ [ACGIH 2004]. The BEI for end-of-shift, end-of-workweek total chromium in urine is $25 \mu \mathrm{g} / \mathrm{L}$. OSHA does not have a legal requirement for levels of urine chromium.

\section{Hexavalent Chromium}

Chromium occurs in several valence states, and hexavalent chromium is commonly used in industry in various paint and primer pigments, graphic art supplies, fungicides, and corrosion inhibitors. Hexavalent chromium is a well-established occupational carcinogen associated with lung cancer and nasal and sinus cancer [NIOSH 2013]. Hexavalent chromium is corrosive and causes chronic ulceration and perforation of the nasal septum and other skin surfaces [IARC 2012]. Allergic dermatitis is one of the most common effects of chromium toxicity among exposed workers. Since hexavalent chromium is reduced to trivalent chromium in red blood cells, the level of total chromium in red blood cells can be an indication of hexavalent chromium exposure [ATSDR 2000].

\section{Aluminum}

Chronic occupational exposure to aluminum dust above the applicable exposure limits may cause pulmonary fibrosis, respiratory irritation, cough, and sore throat [Smolkova and Nakladalova 2014].

\section{Metalworking Fluids}

MWFs are complex mixtures used to cool, lubricate, and remove metal chips from tools and parts during machining of metal stock. MWFs often contain other substances, including biocides, corrosion inhibitors, metal fines, tramp oils, and biological contaminants [NIOSH 1998a; Burton et al. 2012]. Inhalation of MWF aerosols may irritate the throat, nose, and lung and has been associated with chronic bronchitis, asthma, hypersensitivity pneumonitis, and worsening of pre-existing respiratory problems [Burton et al. 2012]. Hypersensitivity pneumonitis is a spectrum of granulomatous, interstitial lung diseases that occur after repeated inhalation and sensitization to one or more of a wide variety of microbial agents (bacteria, fungi, or amoebae), animal proteins, and low-molecular-weight chemical antigens [CDC 1996; Kreiss and Cox-Ganser 1997; Zacharisen et al. 1998].

Skin contact with MWFs may cause allergic contact dermatitis or irritant contact dermatitis, depending on the chemical composition, additives and contaminants, type of metal being machined, and the exposed individual's tendency for developing allergies [WISHA 2001]. Synthetic, semisynthetic, and soluble oil MWFs are diluted with water, so bacteria may grow if an inadequate amount of biocide is present. The Health and Safety Executive in the United Kingdom states that well-maintained MWFs have bacterial concentrations below $103 \mathrm{CFU} / \mathrm{mL}$ of fluid [HSE 2006]. Concentrations between 103 and $106 \mathrm{CFU} / \mathrm{mL}$ indicate reasonable control, and concentrations greater than $106 \mathrm{CFU} / \mathrm{mL}$ indicate poor control [HSE 2006]. The outer cell walls of Gram-negative bacteria may release lipopolysaccharide compounds called endotoxin when the bacteria die or multiply. Endotoxin is believed to cause adverse respiratory effects such as chronic bronchitis and asthma. In 2010, the Dutch 
Expert Committee on Occupational Safety recommended a health-based OEL for airborne endotoxin of $90 \mathrm{EU} / \mathrm{m}^{3}$ [DECOS 2010]. Contaminated water in MWFs may also contain fungi. Some fungi may infect susceptible hosts, such as immune compromised persons, and some fungi may cause hypersensitivity pneumonitis. At this time, health data are insufficient to allow us to recommend a specific limit for fungal contamination in MWFs.

\section{Noise}

Noise-induced hearing loss is an irreversible condition that progresses with noise exposure. It is caused by damage to the nerve cells of the inner ear and cannot be treated medically [Berger et al. 2003]. It is estimated that more than 22 million U.S. workers are exposed to workplace noise levels above $85 \mathrm{dBA}$ [Tak et al. 2009] and are at risk of noise-induced hearing loss [NIOSH 1998b].

Although hearing ability commonly declines with age, exposure to excessive noise can increase the rate of hearing loss. In most cases, noise-induced hearing loss develops slowly from repeated exposure to noise over time, but the progression of hearing loss is typically greatest during the first several years of noise exposure. Noise-induced hearing loss can result also from a single noise exposure or one of short duration, depending on the intensity of the noise and the individual's susceptibility [Berger et al. 2003]. Noise-exposed workers can develop substantial hearing loss before it is clearly recognized. Even mild hearing losses can impair a person's ability to understand speech and hear many important sounds. Some people with noise-induced hearing loss also develop "tinnitus." Tinnitus is a condition in which a person perceives sound in one or both ears, but no external sound is present. Persons with tinnitus often describe hearing ringing, hissing, buzzing, whistling, clicking, or chirping like crickets. There is no cure for tinnitus.

The preferred unit for reporting noise measurements is the dBA. A-weighting is used because it approximates the "equal loudness perception characteristics of human hearing for pure tones relative to a reference of $40 \mathrm{~dB}$ at a frequency of $1000 \mathrm{Hertz}(\mathrm{Hz})$ " and is considered to provide a better estimation of hearing loss risk than using unweighted or other weighting measurements [Earshen 2003].

Employees exposed to noise should have baseline and yearly hearing tests to evaluate their hearing thresholds and determine whether their hearing has changed over time. Hearing tests should be done in a quiet location. In workplace hearing conservation programs, hearing thresholds must be measured at 500, 1000, 2000, 3000, 4000, and $6000 \mathrm{~Hz}$. Additionally, NIOSH recommends that $8,000 \mathrm{~Hz}$ should also be tested [NIOSH 1998b]. The OSHA hearing conservation standard requires analysis of changes from baseline hearing thresholds to determine if the changes are substantial enough to meet OSHA criteria for a standard threshold shift. OSHA defines a standard threshold shift as a change in hearing threshold (relative to the baseline hearing measurement) of an average of $10 \mathrm{~dB}$ or more at 2000,3000, and $4000 \mathrm{~Hz}$ in either ear [29 CFR 1910.95]. If a standard threshold shift occurs, then the company must determine if the hearing loss also meets the requirements to be recorded on the OSHA 300 Log of Injury and Illness [29 CFR 1904.1]. In contrast to OSHA, NIOSH defines a significant threshold shift as an increase in the hearing threshold level of $15 \mathrm{~dB}$ or 
more, relative to the baseline audiogram, at any test frequency in either ear measured twice in succession [NIOSH 1998b].

NIOSH has an REL for noise of $85 \mathrm{dBA}$, as an 8-hour TWA. For calculating exposure limits, NIOSH uses a 3-dB time/intensity trading relationship, or exchange rate. Exposure to impulsive noise should never exceed $140 \mathrm{dBA}$. For extended work shifts NIOSH adjusts the REL. When noise exposures exceed the REL, NIOSH recommends the use of hearing protection and implementation of a hearing loss prevention program [NIOSH 1998b].

The OSHA noise standard specifies a PEL of $90 \mathrm{dBA}$ and an AL of $85 \mathrm{dBA}$, both as 8-hour TWAs. OSHA uses a less conservative 5-dB exchange rate for calculating the PEL and AL. Exposure to impulsive or impact noise must not exceed $140 \mathrm{~dB}$ peak noise level. OSHA does not adjust the PEL for extended work shifts. However, the AL is adjusted. OSHA requires implementation of a hearing conservation program when noise exposures exceed the AL [29 CFR 1910.95]. 


\section{References}

ACGIH [2001]. Recommended BEI for cobalt, all inorganic forms, except cobalt oxides. Cincinnati, OH: American Conference of Governmental Industrial Hygienists.

ACGIH [2004]. Recommended BEI for chromium and inorganic compounds. Cincinnati, $\mathrm{OH}$ : American Conference of Governmental Industrial Hygienists.

ACGIH [2015]. 2015 TLVs ${ }^{\circledR}$ and BEIs ${ }^{\circledR}$ : threshold limit values for chemical substances and physical agents and biological exposure indices. Cincinnati, OH: American Conference of Governmental Industrial Hygienists.

AIHA [2015]. AIHA 2015 emergency response planning guidelines (ERPG) \& workplace environmental exposure levels (WEEL) Handbook. Fairfax, VA: American Industrial Hygiene Association.

Arrandale VH, Liss GM, Tarlo SM, Pratt MD, Sasseville D, Kudla I, Holness DL [2012]. Occupational contact allergens: are they also associated with occupational asthma? Am J Ind Med 55(4):353-360.

ATSDR [2000]. Toxicological profile for chromium. Atlanta, GA: U.S. Department of Health and Human Services, Public Health Service, Agency for Toxic Substances and Disease Registry.

Berger EH, Royster LH, Royster JD, Driscoll DP, Layne M, eds. [2003]. The noise manual. 5th rev. ed. Fairfax, VA: American Industrial Hygiene Association.

Burton CM, Crook B, Scaife H, Evans GS, Barber CM [2012]. Systematic review of respiratory outbreaks associated with exposure to water based metalworking fluids. Ann Occup Hyg, doi:10.1093/annhyg/mer121. Advance online publication.

CDC (Centers for Disease Control and Prevention) [1996]. Biopsy-confirmed hypersensitivity pneumonitis in automobile production workers exposed to metalworking fluids-Michigan, 1994-1995. MMWR 45(28):606-610.

CFR. Code of Federal Regulations. Washington, DC: U.S. Government Printing Office, Office of the Federal Register.

DECOS [2010]. Endotoxins: health-based recommended occupational exposure limit. The Hague: Health Council of the Netherlands, Dutch Expert Committee on Occupational Safety. [http://www.gezondheidsraad.nl/sites/default/files/201004OSH.pdf]. Date accessed: July 2015.

Earshen J [2003]. Sound measurement: instrumentation and noise descriptors. In Berger EH, Royster LH, Royster JD, Driscoll DP, Layne M, eds. The Noise Manual. 5th rev. ed. Fairfax, VA: American Industrial Hygiene Association.

Gheysens B, Auwerx J, Van den Eeckhout A, Demedts M [1985]. Cobalt-induced bronchial asthma in diamond polishers. Chest 88(5):740-744. 
HSE (Health and Safety Executive) [2006]. Managing sumps and bacterial contamination: control approach 4. COSHH essentials for machining with metalworking fluids, http://www. hse.gov.uk/pubns/guidance/mw05.pdf.

IARC [2012]. IARC monographs on the evaluation of carcinogenic risks to humans. Lyons France: World Health Organization, International Agency for Research on Cancer, pp 147-167. [http://monographs.iarc.fr/ENG/Monographs/vol100C/mono100C-9.pdf]. Date accessed: July 2015.

Kreiss K, Cox-Ganser J [1997]. Metalworking fluid-associated hypersensitivity pneumonitis: a workshop summary. Am J Ind Med 32(4):423-432.

NIOSH [1997]. NIOSH alert: preventing allergic reactions to natural rubber latex in the workplace. Cincinnati, OH: U.S. Department of Health and Human Services, Centers for Disease Control and Prevention, National Institute for Occupational Safety and Health, DHHS (NIOSH) Report No. 97-135.

NIOSH [1998a]. Criteria for a recommended standard: occupational exposure to metalworking fluids. Cincinnati, OH: U.S. Department of Health and Human Services, Centers for Disease Control and Prevention, National Institute for Occupational Safety and Health, DHHS (NIOSH) Publication No. 98-102.

NIOSH [1998b]. Criteria for a recommended standard: occupational noise exposure (revised criteria 1998). Cincinnati, OH: U.S. Department of Health and Human Services, Centers for Disease Control and Prevention, National Institute for Occupational Safety and Health, DHHS (NIOSH) Publication No. 98-126, http://www.cdc.gov/niosh/docs/98-126/.

NIOSH [2010]. NIOSH pocket guide to chemical hazards. Cincinnati, OH: U.S. Department of Health and Human Services, Centers for Disease Control and Prevention, National Institute for Occupational Safety and Health, DHHS (NIOSH) Publication No. 2010-168c, http://www.cdc.gov/niosh/npg/.

NIOSH [2013]. NIOSH criteria for a recommended standard: occupational exposure to hexavalent chromium. Cincinnati, OH: U.S. Department of Health and Human Services, Centers for Disease Control and Prevention, National Institute for Occupational Safety and Health, DHHS (NIOSH) Publication No. 2013-128.

NIOSH [2014a]. NIOSH manual of analytical methods (NMAM®). 4th ed. Schlecht PC, O'Connor PF, eds. Cincinnati, OH: U.S. Department of Health and Human Services, Centers for Disease Control and Prevention, National Institute for Occupational Safety and Health, DHHS (NIOSH) Publication 94-113 (August 1994); 1st Supplement Publication 96-135; 2nd Supplement Publication 98-119; 3rd Supplement 2003-154, http://www.cdc.gov/niosh/ docs/2003-154/.

NIOSH [2014b]. NIOSH manual of analytical methods (NMAM). Consideration of sampler wall deposits. Inclusion of material adhering to internal cassette surfaces during sampling and analysis of airborne particles. [http://www.cdc.gov/niosh/docs/2003-154/cassetteguidance. html]. Date accessed: July 2015. 
OSHA [2015]. Safety and health topics: chromium. Washington, DC: U.S. Department of Labor, Occupational Safety and Health Administration, https://www.osha.gov/SLTC/ chromium/index.html.

Rehfisch P, Anderson M, Berg P, Lampa E, Nordling Y, Svartengren M, Westberg H, Gunnarsson L [2015]. Lung function and respiratory symptoms in hard metal workers exposed to cobalt. JOEM 54(4):409-413.

Sjogren I, Hillerdal G, Andersson A, Zetterstrom O [1980]. Hard metal lung disease: importance of cobalt in coolants. Thorax 35(9):653-659.

Smolkova P, Nakladalova M [2014]. The etiology of occupational pulmonary aluminosis: the past and the present. Biomed Pap Med Fac Univ Palacky Olomouc Czech Repub 158(4):535-538.

Tak S, Davis RR, Calvert GM [2009]. Exposure to hazardous workplace noise and use of hearing protection devices among US workers: NHANES, 1999-2004. Am J Ind Med $52(5): 358-371$.

Walters GI, Moore VC, Robertson AS, Burge CB, Vellore AD, Burge PS [2012]. An outbreak of occupational asthma due to chromium and cobalt. Occup Med 62(7):533-540.

Welling R, Beaumont J, Petersen S, Alexeff G, Steinmaus C [2015]. Chromium VI and stomach cancer: a meta-analysis of the current epidemiological evidence. Occup Environ Med 72(2):151-159.

WISHA [2001]. Preventing occupational dermatitis. Olympia, WA: Washington State Department of Labor and Industries, Safety \& Health Assessment \& Research for Prevention (SHARP) Publication No. 56-01-1999.

Zacharisen MC, Kadambi AR, Schlueter DP, Kurup VP, Shack JB, Fox JL, Anderson HA, Fink JN [1998]. The spectrum of respiratory disease associated with exposure to metalworking fluids. J Occup Environ Med 40(7):640-647. 
Keywords: North American Industry Classification System 339113 (Surgical Appliances and Supplies Manufacturing), surgical implants, surgical device manufacturer, cobalt, chromium, hexavalent chromium, aluminum, metal working fluids, MWF, noise, respiratory, sinus, skin, Florida 
This page left intentionally blank 
The Health Hazard Evaluation Program investigates possible health hazards in the workplace under the authority of the Occupational Safety and Health Act of 1970 (29 U.S.C. § 669(a) (6)). The Health Hazard Evaluation Program also provides, upon request, technical assistance to federal, state, and local agencies to investigate occupational health hazards and to prevent occupational disease or injury. Regulations guiding the Program can be found in Title 42, Code of Federal Regulations, Part 85; Requests for Health Hazard Evaluations (42 CFR Part 85).

\section{Disclaimer}

The recommendations in this report are made on the basis of the findings at the workplace evaluated and may not be applicable to other workplaces.

Mention of any company or product in this report does not constitute endorsement by NIOSH.

Citations to Web sites external to NIOSH do not constitute NIOSH endorsement of the sponsoring organizations or their programs or products. NIOSH is not responsible for the content of these Web sites. All Web addresses referenced in this document were accessible as of the publication date.

\section{Acknowledgments}

Analytical Support: Bureau Veritas North America

Desktop Publisher: Shawna Watts

Editor: Ellen Galloway

Logistics: Donnie Booher and Karl Feldmann

Medical Field Assistance: Barbara MacKenzie

\section{Availability of Report}

Copies of this report have been sent to the employer, employees, and union at the facility. The state and local health department and the Occupational Safety and Health Administration Regional Office have also received a copy. This report is not copyrighted and may be freely reproduced.

This report is available at http://www.cdc.gov/niosh/hhe/reports/pdfs/2013-0033-3238.pdf.

\section{Recommended citation for this report:}

NIOSH [2015]. Health hazard evaluation report: evaluation of skin and respiratory symptoms among employees with exposure to metals, metalworking fluids, and noise at an orthopedic implant manufacturer. By Beaucham C, Tapp L, Mueller C, Oza A. Cincinnati, OH: U.S. Department of Health and Human Services, Centers for Disease Control and Prevention, National Institute for Occupational Safety and Health, NIOSH HHE Report No. 2013-0033-3238. 
Delivering on the Nation's promise:

Safety and health at work for all people through research and prevention

To receive NIOSH documents or more information about occupational safety and health topics, please contact NIOSH:

Telephone: 1-800-CDC-INFO (1-800-232-4636)

TTY: 1-888-232-6348

CDC INFO: www.cdc.gov/info

or visit the NIOSH Web site at www.cdc.gov/niosh

For a monthly update on news at $\mathrm{NIOSH}$, subscribe to

$\mathrm{NIOSH}$ eNews by visiting www.cdc.gov/niosh/eNews. 